\title{
Working
}

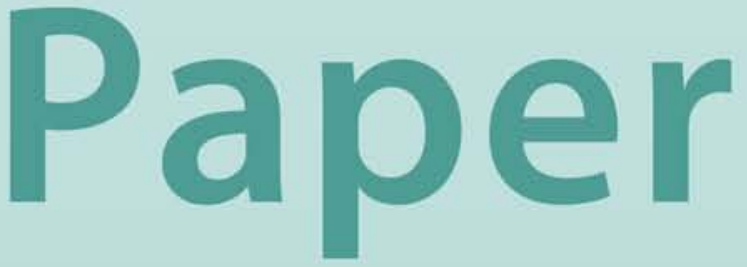




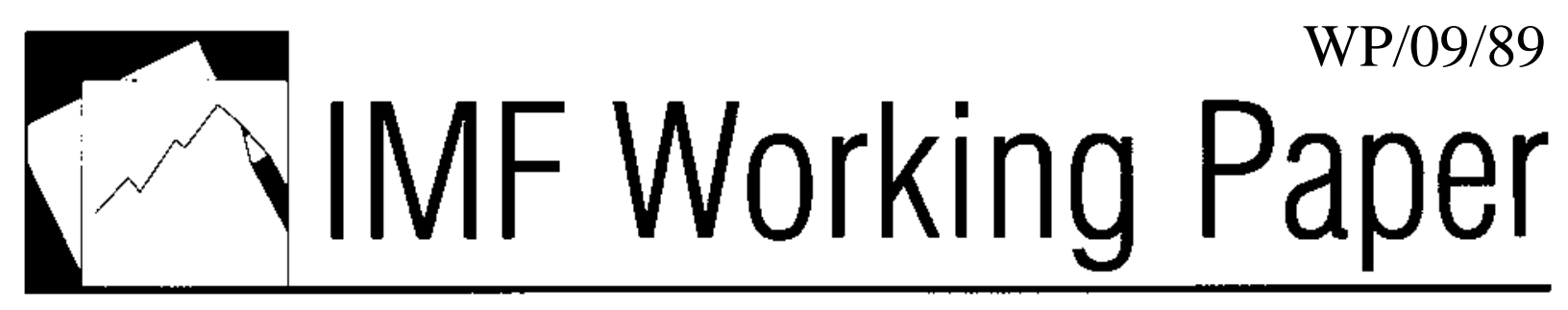

Global Imbalances and Petrodollars

Rabah Arezki and Fuad Hasanov 


\title{
IMF Working Paper
}

IMF Institute and Middle East and Central Asia Department

\section{Global Imbalances and Petrodollars} Prepared by Rabah Arezki and Fuad Hasanov ${ }^{1}$

Authorized for distribution by Marc Quintyn and Timothy Callen

April 2009

\begin{abstract}
This Working Paper should not be reported as representing the views of the IMF. The views expressed in this Working Paper are those of the author and do not necessarily represent those of the IMF or IMF policy. Working Papers describe research in progress by the author and are published to elicit comments and to further debate.

Oil exporters have run large current account surpluses. We explore oil exporters' role in our understanding and the resolution of global imbalances. Current account dynamics are estimated for oil-exporting countries and the rest of the world. We find that fiscal policy has a much stronger effect on current account of oil exporters than on current account of other countries. The current account adjustment of oil-exporting countries is also faster than that of other countries. We conclude that a change in fiscal policy of oil exporters can have significant and speedy impact on global imbalances.
\end{abstract}

JEL Classification Numbers: F32, F42, E62

Keywords: $\quad$ Oil exporters, global imbalances, current account, fiscal policy.

Authors’ E-Mail Addresses: rarezki@imf.org; fhasanov@imf.org

\footnotetext{
${ }^{1}$ We would like to thank Ali Alichi, Rudolf Bems, Tim Callen, Irineu de Carvalho Filho, Enrica Detragiache, Aasim Husain, Mohsin Khan, Leslie Lipschitz, Paulo Mauro, Gian Maria MilesiFerretti, Marc Quintyn, Abdelhak Senhadji, and participants at an IMF Institute Seminar for helpful comments and discussions. All remaining errors are our own.
} 


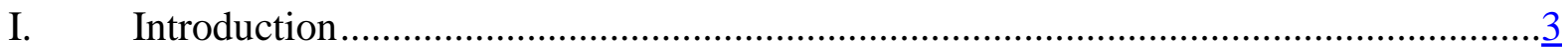

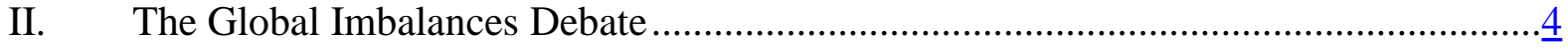

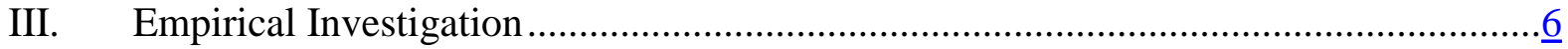

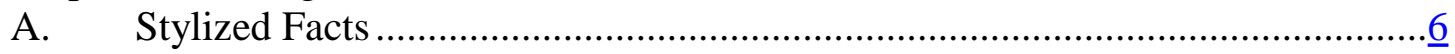

B. Empirical Specification, Data, and Estimators ............................................

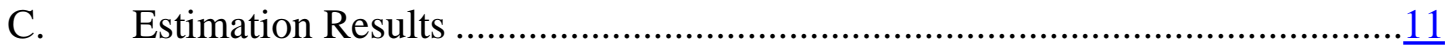

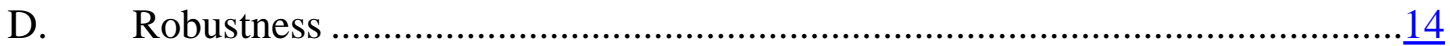

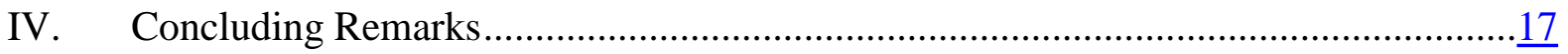

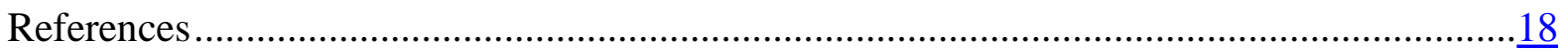

Tables

1. Current Account Estimations (1980-2007, Annual) …................................................ 12

2. Current Account Estimations: Oil Exporters, GMM (1980-2007, Annual).......................15

3. Current Account Estimations (1980-2007, 4-year average)...........................................16

Figures

1. Evolution of Current Account....................................................................................

2. Evolution of Oil Exporters' Current Account and Fiscal Balance: Twin Surpluses .............. $\underline{6}$

3. Evolution of Fiscal Balance .................................................................................... 6

4. NFA, Current Account, and Spending in Oil-Exporting Countries ...................................

5. Fiscal Balance, Revenues, and Spending in Oil-Exporting Countries.................................

Appendices

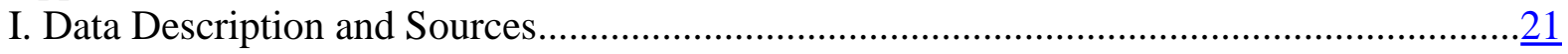

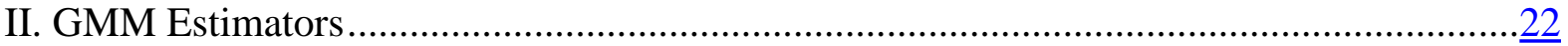

Appendix III Tables

A1. Current Account Estimations: Total Sample (With Outliers, 1980-2007, Annual) ..........23

A2. Current Account Estimations: Oil Exporters, Pooled OLS (1980-2007, Annual) ...........24

A3. Current Account Estimations: Oil Exporters, FE (1980-2007, Annual) ..........................25 


\section{INTRODUCTION}

For the past decade, the world has witnessed emergence of global imbalances-large and persistent current account (CA) surpluses in some countries and CA deficits in others. This phenomenon has been at the forefront of policymaking discussions so as to prevent any disorderly unwinding of global imbalances that could have seriously threatened global growth. As the global financial crisis unfolded in 2008, one explanation put forth was the existing global imbalances. Regardless, the crisis seems to have brought some of the adjustment forward although the extent and magnitude of this adjustment is yet to be seen. On the other hand, the current crisis may even result in widening global imbalances in the future. Indeed, the Asian crisis of 1997-1998 contributed to policy shifts in Asian countries resulting in large CA surpluses and accumulation of international reserves. As the world economy recovers, the rising oil price would leave oil exporters awash with petrodollars once again. Whether the US consumer plans to tighten her belt in the medium term is also an open question. Global imbalances are thus unlikely to remain a policy issue of the past. In this paper, we explore the role played by oil-exporting countries in global imbalances.

Oil-exporting countries have contributed significantly to the emergence of global imbalances. ${ }^{2}$ Indeed, as shown in Figure 1, oil exporters experienced a sharp increase in current account surpluses amounting to \$466 billion in 2007 compared to \$518 billion for Emerging Asia. ${ }^{3}$ The forecast for 2008 exceeds that of Asia. These surplus countries seem to mirror the deficit of the United States (Figure 1).

Figure 1. Evolution of Current Account

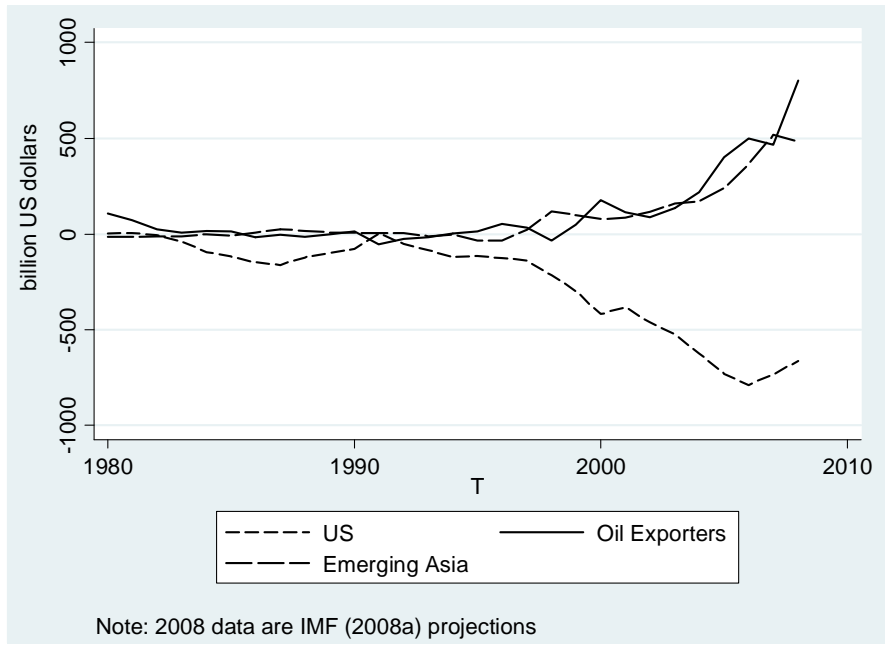

${ }^{2}$ Oil/gas exporting countries are Algeria, Angola, Azerbaijan, Bahrain, Congo, Ecuador, Equatorial Guinea, Gabon, Iran, Kazakhstan, Kuwait, Libya, Nigeria, Norway, Oman, Qatar, Russia, Saudi Arabia, Syria, Turkmenistan, United Arab Emirates, Venezuela, and Yemen.

${ }^{3}$ Emerging Asia comprises China, Hong Kong, India, Indonesia, Korea, Malaysia, Philippines, Singapore, Taiwan Province of China, Thailand, and Vietnam. 
Although oil exporters have run large current account surpluses, to our knowledge, the impact of these countries' policies on global imbalances has not been studied. ${ }^{4}$ Perhaps it is due to the supposition the oil price is the only driver of oil exporters' current account. With lower oil prices amid the severe global downturn, current account surplus of oil exporters could indeed fall while current account of oil importers could improve. Yet it is unclear if global imbalances would shrink as imports of oil exporters and exports of oil importers might decline drastically as well. If the oil price were the only relevant factor in driving current account behavior, oil exporters' policies would not matter in resolving global imbalances.

We contend oil exporters play a more active role in the global economy than what is commonly thought. Fiscal restraint on the part of oil exporters would support their current account surpluses contributing further to global imbalances. Fiscal spending would absorb world exports allowing for the global imbalances adjustment. The destination choice (countries, instruments, etc.) of accumulated petrodollars of sovereign wealth funds (SWFs) would also be important in correcting global imbalances. As oil prices rise, these issues would become even more pressing. Oil exporters’ policies do matter.

To investigate whether oil-exporters' current account behavior and policy options differ from the rest of the world, we estimate current account regressions for the respective samples. We use pooled OLS, fixed effects, and generalized method of moment (GMM) estimators. The GMM estimator is important conceptually due to endogeneity of regressors, and we examine how it performs empirically. We find that fiscal policy has a much stronger effect on current account of oil exporters than on current account of other countries. A 1 percentage change in the fiscal balance affects current account by 0.9-1.4 percentage points (compared to 0.3-0.4 percent for other countries). The current account adjustment of oil-exporting countries is also faster than that of other countries. We conclude that a change in fiscal policy of oil exporters can have significant impact on global imbalances. As is currently evident, lower persistence of oil exporters' current account can also speed up the adjustment of global imbalances.

Section II discusses previous literature relevant for our study. The empirical analysis is presented in Section III. Subsection A shows some stylized facts; subsection B presents the main empirical specification, data, and estimators; subsection $\mathrm{C}$ discusses results; and subsection D performs robustness checks. Section IV concludes.

\section{The Global Imbalances DeBATE}

Two main explanations for the emergence of global imbalances have been put forward. The decline in US saving, especially driven by the increasing US federal deficit since 2002 is said

\footnotetext{
${ }^{4}$ Most previous studies either exclude oil exporters or use an oil exporter dummy. Arezki (2007) and Hasanov and Senhadji (2008) examine current account determinants for the Middle East and Central Asian oil exporters. IMF (2008b) has a short discussion of current account determinants for a larger set of oil-exporting countries.
} 
to be a primary source of the widening US current account deficit over the past decade. Known as the twin deficit hypothesis, it is not, however, an all-inclusive explanation of the large US current account deficit. ${ }^{5}$ Others (see, for instance, Bernanke, 2005) have argued that the roots of global imbalances lie outside the US. The "oversaving" behavior of the Asian countries generated a "saving glut" and excesses were absorbed by developed countries, among which the US was the largest recipient. Some have even argued that it was an act of "good global citizenship" as the US absorbed the world saving surplus (Clarida, 2005a, 2005b).

Chinn and Ito (2007, 2008) and Gruber and Kamin (2007) attempt to explain the upswing since 1997 from current account deficit to surplus in Asian countries. They use a framework of the earlier work by Chinn and Prasad (2003) who developed an empirical model of the current account determination. Both papers find that determinants used in Chinn and Prasad (2003) such as demographics and income variables alone do not explain the upswing in Asian countries' current account. Gruber and Kamin (2007) find that financial crises could help explain a reduction in aggregate demand in Asia resulting in improved current account position. Chinn and Ito (2007) augment Chinn and Prasad (2003) specification with indicators of financial development and legal environment that are likely to affect saving/investment behavior and economic growth. They find that the interaction of legal environment with financial development plays a significant role in explaining capital outflows from Asia. They reject the saving glut hypothesis. On the contrary, their results suggest that it is the lack of investment opportunities rather than excess saving that helps explain current account improvement in Asian countries over the last decade.

Some recent empirical literature has focused on investigating solutions to correct global imbalances. Edwards (2007) tests empirically whether rebalancing of world growth with lower economic growth in the US and higher growth in Europe and Japan could help correct global imbalances. His results provide some evidence that growth rebalancing in the global economy will not substantially lower the imbalances. Indeed, he finds that a decline of one percentage point of growth will lead to a decline in current account (bigger deficit or lower surplus) of a quarter-percentage point. Instead, Edwards argues that substantial exchange rate adjustment in China would be needed to lower global imbalances.

The past literature is, however, mute on the role of oil exporters in global imbalances. Oil exporters have accumulated large current account surpluses and such significant flows of petrodollars cannot be ignored in the global imbalances debate. The next section investigates this issue more closely.

\footnotetext{
${ }^{5}$ Greenspan (2005a, b) and Ferguson (2004), among others, claim that fiscal policy plays a relatively minor role in determining current account. Corsetti and Muller (2006) show that the US fiscal policy had a limited impact on the country's current account.
} 


\section{EMPIRICAL INVESTIGATION}

\section{A. Stylized Facts}

Oil price dynamics are important in determining export revenues of oil exporters that in turn affect their external balances. Figure 2 shows that the evolution of oil exporters' current account follows closely the evolution of oil prices. The boom and bust cycles of oil prices transmit to the current account balances of oil exporters.

Governments in oil-exporting countries play an overwhelming role in determining internal saving, resulting in twin surpluses (Figure 2). Many oil-exporting countries suffer from the lack of diversification and rely heavily on oil revenues. Figure 3 shows different dynamics of the fiscal balance in oil-exporting countries compared to the US and emerging Asian countries.

Figure 2. Evolution of Oil Exporters' Current Account and Fiscal Balance: Twin Surpluses

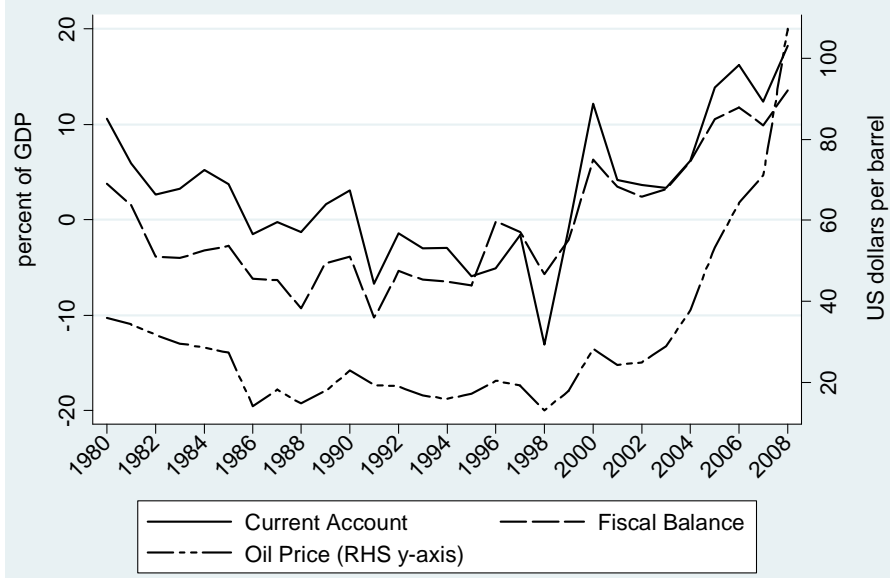

Note : 2008 data are IMF (2008a) projections

Figure 3. Evolution of Fiscal Balance

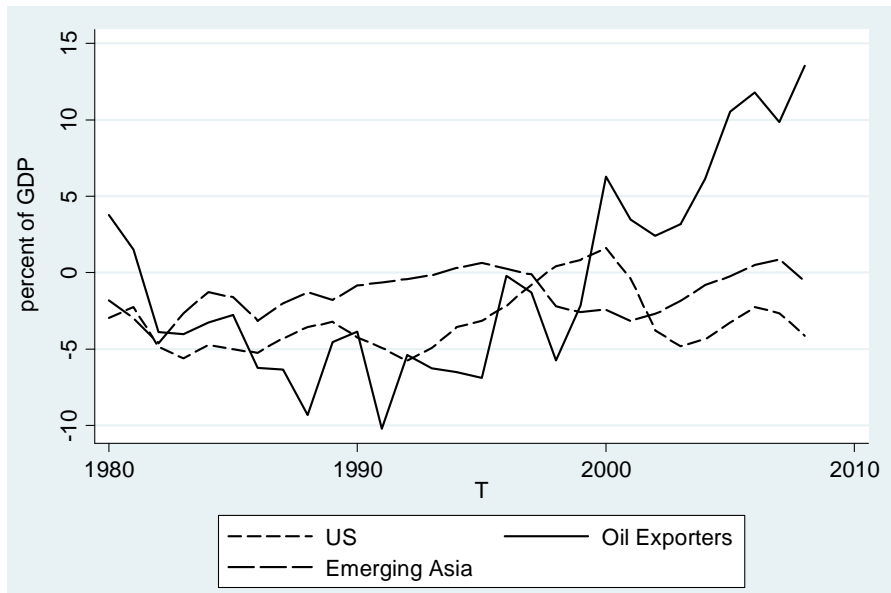

Note: 2008 data are IMF (2008a) projections 
However, the oil price dynamics are not the only relevant factor, and fiscal policy matters. Notwithstanding non-oil revenues, oil sector revenues would also be determined by the oil sector's tax and ownership structure and production volumes. More importantly, upon receipt of oil money, governments of oil-exporting countries could either spend it or accumulate it as net foreign assets (NFA). Government spending seems to have followed boom-bust oil cycles since the 1980s (Figures 4 and 5). However, these economies have also recently accumulated large external assets in SWFs as spending has increased by less than oil revenues, boosting both the fiscal balance and current account (Figures 4 and 5). The accumulated net foreign assets could be drawn upon in the future and thus allow future spending to decouple from oil revenues.

Government's decision to spend or accumulate net foreign assets can either reduce or exacerbate global imbalances. Currently, many oil-exporting countries are undertaking large investment projects in their own countries and their respective regions. According to the Institute of International Finance (2007), external assets have been invested in both portfolio investment and foreign direct investment (FDI) that could keep financing global imbalances. Whether net foreign assets are held in the form of FDI or short-term portfolio investment and are lent to the private sector or government may also have different implications on the future dynamics of global imbalances. FDI is likely to insure a more benign unwinding of global imbalances as FDI-recipient countries grow and develop and become able to sustain their external balances.

Figure 4. NFA, Current Account, and Spending in Oil-Exporting Countries

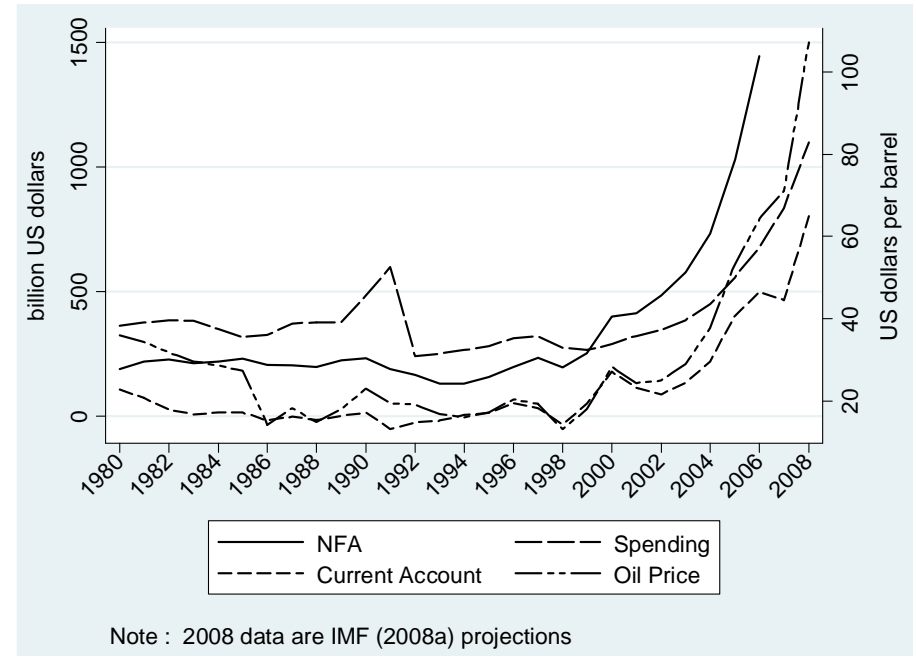


Figure 5. Fiscal Balance, Revenues, and Spending in Oil-Exporting Countries

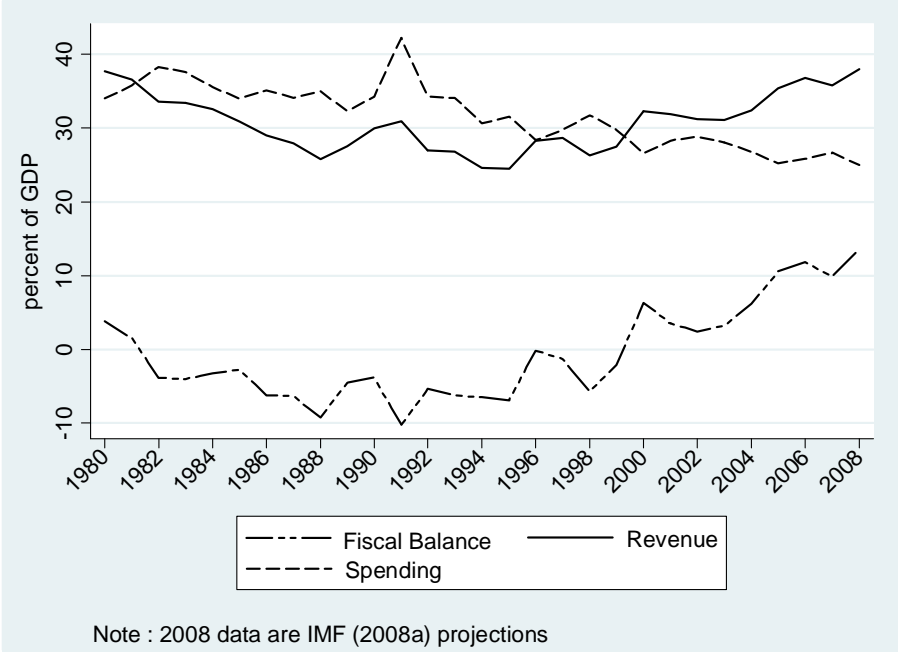

\section{B. Empirical Specification, Data, and Estimators}

Our baseline empirical model uses common current account determinants found in the literature. ${ }^{6}$ The dependent variable is the current account to GDP ratio. The regressors include lagged current account, fiscal balance to GDP, the dependency ratio, net foreign assets to GDP, terms of trade, economic growth, relative income, real effective exchange rate, trade openness, G7 real growth, and G7 real interest rate. Appendix I provides a detailed description of the variables and data sources. Below is a brief discussion of the variables used in the analysis.

Lagged current account: Theoretically, there is a good argument to introduce current account persistence in our specifications. Both habit formation in consumption/saving and agglomeration effects in investment suggest including a lagged dependent variable. Persistence in omitted variables may also call for a dynamic specification.

Fiscal balance: An increase in the fiscal balance is expected to increase national saving and in turn current account in the absence of Ricardian equivalence. In oil-exporting countries, a large share of fiscal revenues comes from oil export revenues and returns from assets invested abroad rather than tax receipts. Governments in oil-exporting countries also play a large role in laying down the investment strategy. Thus the relationship between the fiscal balance and current account might be even more pronounced.

\footnotetext{
${ }^{6}$ See Calderon, Chong, and Loayza (2002), Chinn and Prasad (2003), Gruber and Kamin (2007), Calderon, Chong, and Zanforlin (2007), Chinn and Ito (2007, 2008), and IMF (2008b).
} 
Dependency ratio: Demographics are important determinants of private saving. According to the life-cycle hypothesis, an increase in the dependency ratio (increase in the share of the young and the old), is likely to be associated with lower national saving and lower current account. There is no consensus on the theoretical impact of demographics on investment. ${ }^{7}$

Net foreign assets (NFA): Economies with a relatively high level of NFA can afford to run trade deficits for an extended period and still remain solvent, potentially leading to a negative association between NFA and current account. On the other hand, economies with higher NFA benefit from higher investment income from abroad, which tends to create a positive association between NFA and current account. Standard open economy macroeconomic models predict that the second effect should be stronger.

Terms of trade: Terms of trade account for both export and import prices and thus are an important determinant of current account. Positive terms of trade shocks, ceteris paribus, would improve current account.

Economic growth: The current account balance is expected to fall with an increase in economic growth. Higher productivity growth rates should encourage capital inflows and investment/consumption.

Relative income: It captures a stage of economic development. At lower stages, a country runs current account deficits as it imports capital. At advanced stages, it runs surpluses to repay accumulated debt and export capital. The relationship between relative income and current account is expected to be positive.

Real effective exchange rate (REER): An increase in the REER is likely to lower exports and increase imports. Yet the overall effect on the trade balance depends on the relative size of the import and export volume elasticity assuming full pass-through of the exchange rate to relative prices. A change in the REER may also have a balance sheet effect on a country's NFA and affect remittance flows (Faini, 1994). All-in-all, the relationship between the REER and current account is most likely to be negative.

Trade openness: Trade openness controls for various trade restrictions that are likely to impede a flow of goods and services. The presence of restrictions is also likely to act as an adverse signal to foreign investors. Trade openness is likely to be associated negatively with current account.

G7 growth and interest rate: An increase in economic performance in the major industrialized countries (also proxying for world economic conditions) is likely to limit a

\footnotetext{
${ }^{7}$ Higgins (1998) provides empirical evidence on the relevance of demographic differences in driving international capital movements.
} 
pool of available investment to developing and emerging countries and increase the demand for their exports. G7 real interest rate is likely to have a positive association with current account as well. As international capital gets cheaper, more countries are likely to tap international markets to finance their spending and more investors will probably search for attractive returns in the developing world.

As we investigate whether oil exporters' current account dynamics differ, we split our sample between oil exporters and the rest of the world. The estimation sample uses the annual data for 115 countries for the global sample (less oil exporters) and 21 countries for oil exporters over the period $1980-2007 .^{8}$

We use three estimators - pooled OLS, FE, and GMM-System (Blundell and Bond, 1998). Pooled OLS and FE estimators were used in most previous studies. However, these estimators suffer from important shortcomings if the underlying assumption of strict exogeneity of the independent variables does not hold. This underlying assumption implies that the error term is uncorrelated with all past and future values of regressors. This is a very strong assumption for the proposed specification. In addition, a FE estimator is biased in the presence of the lagged dependent variable although it allows for correlation between the fixed effect and regressors (which is not the case for pooled OLS). ${ }^{9}$ Thus, an alternative estimation method is warranted. Blundell and Bond (1998) argue for the use of the GMM estimator that controls for endogeneity of regressors in a dynamic panel data setting. GMMSystem (GMM-Sys) uses additional moment conditions incorporating a cross-sectional variation in the data in addition to a temporal variation used by GMM-Difference (GMMDiff) proposed by Arellano and Bond (1991). ${ }^{10}$ GMM-Sys has better small-sample properties, especially in the presence of persistent regressors (Blundell and Bond, 1998, and Bond, Hoeffler, and Temple, 2001).

Two specification tests are used to ascertain validity of instruments. $\mathrm{m} 2$ test for second-order autocorrelation allows us to check whether residuals are autocorrelated and assess the validity of our lagged instruments. Hansen's J test of overidentifying restrictions allows us to test overall validity of instruments and thus to check whether a model is misspecified. Rejecting the null hypotheses of $\mathrm{m} 2$ and $\mathrm{J}$ tests would give support to instruments used and the model. ${ }^{11}$ The instruments employed are regressors lagged once with the exception of relative income and the REER that are lagged twice. For oil exporters, G7 growth and interest rate instruments are not lagged. To mitigate the problem of overinstrumentation, each

\footnotetext{
${ }^{8}$ Turkmenistan and Yemen drop out from the estimated sample due to missing observations.

${ }^{9}$ The bias is in the order of $1 / T$.

${ }^{10}$ See a brief discussion on GMM estimators in Appendix II.

${ }^{11}$ We use a one-step estimator with robust standard errors.
} 
instrument corresponds to all time periods rather than a particular time period, and thus the number of moment conditions is independent of the time periods.

In the following subsection, we present our estimation results for our baseline specification followed by the subsection on robustness.

\section{Estimation Results}

The fiscal policy impact on current account for oil exporters is much larger than that for the rest of the world (Table 1 ). ${ }^{12}$ The short-term coefficient ranges from 0.5 to 0.85 across three estimators with the long-term effect from 0.9 to $1.4 .{ }^{13}$ The GMM estimate implies that a one percentage point increase in the government's budget balance (as a percent of GDP) leads to a 0.85 percentage point increase in current account (as a percent of GDP) in the short run and a 1.4 percent increase in the longer run. Pooled OLS and FE estimates imply a bit smaller effect but still quite substantial (0.5-0.6 in the short run and 0.9-1 in the long run). This result contrasts sharply with the estimate for the rest of the world. The short run effect of the fiscal balance is in the range of 0.1-0.16 with the long-term coefficient of 0.3-0.4. The effect of the fiscal balance on current account for the rest of the world is much smaller and is similar to that found in the past literature. ${ }^{14}$

Two reasons may account for such a large effect of the fiscal balance in oil-exporting countries. First, governments play a much larger role in many of these countries than in other countries, especially developed ones. Second, as many oil-exporting countries are relatively not diversified and accrue large oil revenues, the link between public saving and current account is much stronger. If we take the GMM estimate at face value, this link is not mere correlation. The impact of the fiscal balance on current account is a partial causal effect as we exploit an exogenous variation in the fiscal balance using instrumental variables and control for other regressors, especially terms of trade. An important implication is that fiscal policy of oil exporters can play an important role in resolving global imbalances.

\footnotetext{
${ }^{12}$ We exclude potential outliers from the estimation sample although results hold using the total sample (Appendix III, Table A1). To account for the presence of outliers, observations with excessively high leverage were excluded from the sample. More precisely, all observations with DFBETAi,j statistic (with $i$ indicating a country and $j$ a time period) above a certain absolute threshold were dropped. We use a more conservative cutoff value than suggested in the literature- $-2 / \sqrt{n}$ with $n$ being the number of observations in the original sample (Davidson and MacKinnon, 1993, pp. 32-39, and Besley, Kuh, and Welsch, 1980). The total number of observations dropped is less than 5 percent of the total sample.

${ }^{13}$ In a one-lag dynamic model, a long-term coefficient equals a short-term coefficient (the coefficient associated with a variable of interest) divided by one minus a coefficient associated with the lagged dependent variable.

${ }^{14}$ In the following subsection, we address a potential identification issue that could arise when using fiscal balance as a proxy for fiscal policy given the importance of oil revenues in total revenues. We estimate separately the impact of spending and revenues and find that the coefficient associated with spending is both statistically and economically significant (-0.77) and is much larger than that for the global sample (-0.11).
} 
Table 1. Current Account Estimations (1980-2007, Annual)

\begin{tabular}{|c|c|c|c|c|c|c|}
\hline & \multicolumn{2}{|c|}{ Pooled OLS } & \multicolumn{2}{|c|}{ Fixed effects } & \multicolumn{2}{|c|}{ GMM-Sys } \\
\hline & Global & $\begin{array}{c}\text { Oil } \\
\text { exporters }\end{array}$ & Global & $\begin{array}{c}\text { Oil } \\
\text { exporters }\end{array}$ & Global & $\begin{array}{c}\text { Oil } \\
\text { exporters }\end{array}$ \\
\hline Lagged current account & $\begin{array}{c}0.79 * * * \\
(0.02)\end{array}$ & $\begin{array}{c}0.52 * * * \\
(0.04)\end{array}$ & $\begin{array}{c}0.65^{* * * *} \\
(0.02)\end{array}$ & $\begin{array}{c}0.36 * * * \\
(0.05)\end{array}$ & $\begin{array}{c}0.57^{* * * *} \\
(0.05)\end{array}$ & $\begin{array}{c}0.41^{* * *} \\
(0.1)\end{array}$ \\
\hline Fiscal balance & $\begin{array}{c}0.078 * * * \\
(0.02)\end{array}$ & $\begin{array}{c}0.48^{* * * *} \\
(0.05)\end{array}$ & $\begin{array}{c}0.100^{* * * *} \\
(0.02)\end{array}$ & $\begin{array}{c}0.57 * * * \\
(0.06)\end{array}$ & $\begin{array}{c}0.16^{* * * *} \\
(0.06)\end{array}$ & $\begin{array}{c}0.85^{* * *} \\
(0.1)\end{array}$ \\
\hline Dependency ratio & $\begin{array}{c}-0.013^{* * *} \\
(0.005)\end{array}$ & $\begin{array}{c}0.061^{* *} \\
(0.03)\end{array}$ & $\begin{array}{c}-0.062 * * * \\
(0.01)\end{array}$ & $\begin{array}{l}0.027 \\
(0.05)\end{array}$ & $\begin{array}{l}-0.091 \\
(0.06)\end{array}$ & $\begin{array}{c}0.068 \\
(0.1)\end{array}$ \\
\hline NFA & $\begin{array}{c}0.0047^{* * *} \\
(0.001)\end{array}$ & $\begin{array}{c}0.016^{* * *} \\
(0.005)\end{array}$ & $\begin{array}{c}-0.0018 \\
(0.002)\end{array}$ & $\begin{array}{c}0.013 \\
(0.008)\end{array}$ & $\begin{array}{l}0.0020 \\
(0.008)\end{array}$ & $\begin{array}{l}0.030 \\
(0.02)\end{array}$ \\
\hline Terms of trade & $\begin{array}{c}0.55^{* * *} \\
(0.2)\end{array}$ & $\begin{array}{c}3.43^{* * *} \\
(0.9)\end{array}$ & $\begin{array}{c}1.38^{* * * *} \\
(0.3)\end{array}$ & $\begin{array}{c}5.55^{* * *} \\
(1.0)\end{array}$ & $\begin{array}{c}7.92 * * * \\
(2.5)\end{array}$ & $\begin{array}{c}7.70 * * * \\
(2.9)\end{array}$ \\
\hline Economic growth & $\begin{array}{c}-0.11^{* * *} \\
(0.02)\end{array}$ & $\begin{array}{l}-0.033 \\
(0.06)\end{array}$ & $\begin{array}{c}-0.12 * * * \\
(0.02)\end{array}$ & $\begin{array}{l}0.022 \\
(0.06)\end{array}$ & $\begin{array}{c}-0.10^{* * *} \\
(0.03)\end{array}$ & $\begin{array}{l}-0.026 \\
(0.06)\end{array}$ \\
\hline Relative income & $\begin{array}{l}0.0024 \\
(0.003)\end{array}$ & $\begin{array}{c}0.0092 \\
(0.01)\end{array}$ & $\begin{array}{c}-0.044^{* *} \\
(0.02)\end{array}$ & $\begin{array}{l}0.018 \\
(0.03)\end{array}$ & $\begin{array}{l}-0.047 \\
(0.03)\end{array}$ & $\begin{array}{l}-0.035 \\
(0.07)\end{array}$ \\
\hline REER & $\begin{array}{c}-0.56^{* * *} \\
(0.2)\end{array}$ & $\begin{array}{c}-2.46^{* * *} \\
(0.7)\end{array}$ & $\begin{array}{c}-1.02 * * * \\
(0.3)\end{array}$ & $\begin{array}{c}-3.52^{* * * *} \\
(0.8)\end{array}$ & $\begin{array}{l}-2.51 \\
(1.9)\end{array}$ & $\begin{array}{l}-4.51 \\
(3.7)\end{array}$ \\
\hline Trade openness & $\begin{array}{l}0.0015 \\
(0.001)\end{array}$ & $\begin{array}{c}-0.023^{* *} \\
(0.010)\end{array}$ & $\begin{array}{l}-0.0024 \\
(0.005)\end{array}$ & $\begin{array}{c}-0.079^{* * *} \\
(0.02)\end{array}$ & $\begin{array}{l}-0.032 \\
(0.03)\end{array}$ & $\begin{array}{l}0.052 \\
(0.05)\end{array}$ \\
\hline G7 growth & $\begin{array}{l}0.076 \\
(0.05)\end{array}$ & $\begin{array}{c}1.55^{* * *} \\
(0.3)\end{array}$ & $\begin{array}{l}0.070 \\
(0.05)\end{array}$ & $\begin{array}{c}1.13^{* * *} \\
(0.3)\end{array}$ & $\begin{array}{c}0.21^{* *} \\
(0.08)\end{array}$ & $\begin{array}{c}1.07^{* * *} \\
(0.3)\end{array}$ \\
\hline G7 interest rate & $\begin{array}{l}0.058 \\
(0.04)\end{array}$ & $\begin{array}{l}-0.39 \\
(0.3)\end{array}$ & $\begin{array}{l}0.053 \\
(0.05)\end{array}$ & $\begin{array}{c}0.032 \\
(0.3)\end{array}$ & $\begin{array}{l}-0.11 \\
(0.2)\end{array}$ & $\begin{array}{c}0.94 * \\
(0.6)\end{array}$ \\
\hline Constant & $\begin{array}{l}0.57 \\
(1.2) \\
\end{array}$ & $\begin{array}{r}-6.54 \\
(5.1) \\
\end{array}$ & $\begin{array}{l}3.29 \\
(2.1) \\
\end{array}$ & $\begin{array}{r}-4.18 \\
(6.6) \\
\end{array}$ & $\begin{array}{c}-15.9 \\
(12) \\
\end{array}$ & $\begin{array}{l}-22.4 \\
(21) \\
\end{array}$ \\
\hline Fiscal balance (long-term) & $\begin{array}{c}0.38^{* * *} \\
(0.08)\end{array}$ & $\begin{array}{c}1.00^{* * *} \\
(0.09)\end{array}$ & $\begin{array}{c}0.28^{* * * *} \\
(0.06)\end{array}$ & $\begin{array}{c}0.90 * * * \\
(0.08)\end{array}$ & $\begin{array}{c}0.38 * * \\
(0.2)\end{array}$ & $\begin{array}{c}1.43^{* * *} \\
(0.4)\end{array}$ \\
\hline $\mathrm{R}^{2}$ & 0.75 & 0.73 & 0.50 & 0.62 & & \\
\hline Adjusted $\mathrm{R}^{2}$ & 0.75 & 0.72 & 0.50 & 0.60 & & \\
\hline m1 (p-value) & & & & & 0.00 & 0.02 \\
\hline m2 (p-value) & & & & & 0.08 & 0.55 \\
\hline J-test ( $p$-value) & & & & & 0.32 & 0.32 \\
\hline Observations & 2342 & 399 & 2342 & 399 & 2342 & 399 \\
\hline Number of countries & & & 115 & 21 & 115 & 21 \\
\hline
\end{tabular}

Notes: Robust standard errors in parentheses.

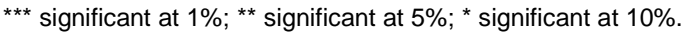

The sample excludes outliers.

Instruments for GMM-Sys: First lags of regressors; relative income and REER are lagged twice.

For oil exporters, $\mathrm{G} 7$ growth and interest rate instruments use contemporaneous values.

$\mathrm{m} 1:$ Test for 1st order serial correlation in differences.

$\mathrm{m} 2$ : Test for 2 nd order serial correlation in differences. J-test: Test for overidentifying restrictions. 
The faster speed of adjustment of current account for oil exporters is another finding different for two samples. Indeed, the coefficient associated with the lagged dependent variable is lower at $0.36-0.52$ vs. $0.57-0.8$ for the global sample. Using the GMM estimate, the impact of a shock to current account at time $t$ would take about 0.8 years to dissipate by one-half for oil exporters while it would take 1.2 years for the rest of the world. ${ }^{15}$ This difference is larger if we use pooled OLS ( 1 year vs. 3 years) or FE estimates ( 0.7 vs. 1.6$)$. Oil exporters' heavy reliance on oil exports and revenues certainly explains the difference in the persistence of current account between oil exporters and other countries. ${ }^{16}$ Importantly, this result suggests that even though oil-exporting countries are large surplus countries, these imbalances are less persistent than those in other countries and have a potential to adjust faster.

The terms of trade impact on current account is as strong in oil exporters as in the rest of the world using GMM estimates. A one percent increase of terms of trade, all else equal, increases current account by about 0.08 percent. This result is in contrast to that obtained using Pooled OLS and FE estimates. One potential explanation is that controlling for endogeneity, we obtain a similar impact of terms of trade shock on current account in both oil exporters and other countries.

The association of the REER with current account is negative and statistically significant while the coefficient is larger for oil exporters, using pooled OLS and FE. For instance, the FE estimate of -3.5 (semi-elasticity) suggests a one percent increase in the REER is related with a 0.035 percent decline in current account. Approximately, a 100 percent appreciation of the REER is required to reduce current account of oil exporters by a 2.4 percent. It indicates a large adjustment, indeed. Yet, interestingly, accounting for endogeneity with GMM, we find that the impact of the REER is insignificant although correctly signed in both samples. As most exports are in US dollars and imports are primarily driven by the government investment strategy, we may expect a relatively small economic effect of the REER on current account of oil exporters.

It is also worth noting that economic growth has a negative impact on current account only for the global sample while G7 growth has a positive impact in both samples. As G7 growth proxies for world economic conditions, it is not surprising to find that the impact is positive as demand for exports rises and capital flows increase disproportionately in the developed countries. The relationship between a country's growth and its current account is, however, negative as investment increases by more than saving with higher growth.

\footnotetext{
${ }^{15}$ The half-life is computed as $\log (0.5) / \log (\alpha)$ where $\alpha$ is the coefficient estimate on the lagged dependent variable.

${ }^{16}$ Calderon, Chong, and Zanforlin (2007) find a similar result for African countries, most of which are commodity exporters.
} 
These estimations show that controlling for major current account determinants, including terms of trade, a strong driver of CA behavior, fiscal policy is an important factor in the current account dynamics. Oil exporters influence global imbalances through fiscal policies.

\section{Robustness}

We obtain similar results when adding other potential explanatory variables to our baseline specification (Table 2). We experiment with financial development proxied by private credit to GDP, the oil price instead of terms of trade, oil price volatility (measured as standard deviation of monthly oil prices) to account for precautionary saving, gross FDI flows (as a percent of GDP) that allows for a stable source of financing, and time dummies for common shocks. The financial development variable is significant at 10 percent with a negative sign. With deeper financial development, more borrowing, and larger investment opportunities, current account would decline. With the time dummies specification, the terms of trade variable is no longer significant as dummies probably pick up the effect of terms of trade shocks. The coefficient on the oil price in Table 2 is positive and close in magnitude to the terms of trade coefficient in Table 1, but it is only significant at the 10 percent level. The specification tests suggest that instruments used may not be valid. This result also implies that it is not only the export price but the import price as well that matters in the current account dynamics of oil exporters. Lastly, including oil price volatility or gross FDI and excluding the REER from the baseline specification, our results do not change.

The last two columns in Table 2 exclude the fiscal balance and use only revenue and expenditure variables. One may argue that the fiscal balance picks up the effect of only oil revenues (though we showed that the impact of the fiscal balance is large even after controlling for terms of trade or the oil price). The results show that both variables are statistically significant and the expenditure variable is negative. The fiscal policy is a major determinant in the current account dynamics of oil exporters. Even though a government may have less control over its oil revenues, it does have a stronger say in whether to spend or not, affecting public saving and in turn current account.

The estimation results using pooled OLS and FE estimators are presented in Appendix III, Tables A2-A3. The coefficients on private credit, oil price, and oil price volatility are statistically significant unlike GMM estimates, which show weaker statistical significance.

Table 3 presents estimation results with 4-year average observations to account for cyclical fluctuations in the data. The results are qualitatively similar but quantitatively, we find somewhat smaller coefficients on the fiscal balance and the lagged dependent variable and statistical insignificance of the terms of trade estimate for oil exporters. Of course, with 4year averages, it is not surprising that the persistence of current account is much smaller. The long-run impact of the fiscal balance is smaller than that using GMM in the annual estimation, but it is similar to that using pooled OLS and FE with the annual data. We also find that the lagged level of net foreign assets has a positive and statistically significant effect 
while trade openness has a negative effect on current account of oil exporters. Perhaps in the longer run, the effect of terms of trade is not as pronounced as the effects of NFA and trade openness. Similarly, estimation results using pooled OLS and FE show more significant variables but one should be cautious in interpreting these effects as causal. All-in-all, we find that our main results are robust to various specifications, data frequency, and the inclusion of eliminated outliers (Table 3 and Appendix III tables).

Table 2. Current Account Estimations: Oil Exporters, GMM (1980-2007, Annual)

\begin{tabular}{|c|c|c|c|c|c|c|c|c|}
\hline Lagged current account & $\begin{array}{c}0.62^{* * *} \\
(0.1)\end{array}$ & $\begin{array}{c}0.35^{* * *} \\
(0.1)\end{array}$ & $\begin{array}{c}0.40^{* * *} \\
(0.1)\end{array}$ & $\begin{array}{c}0.41^{* * *} \\
(0.1)\end{array}$ & $\begin{array}{c}0.35^{* * *} \\
(0.08)\end{array}$ & $\begin{array}{c}0.39 * * * \\
(0.1)\end{array}$ & $\begin{array}{c}0.39 * * * \\
(0.1)\end{array}$ & $\begin{array}{c}0.53^{* * *} \\
(0.1)\end{array}$ \\
\hline Fiscal balance & $\begin{array}{c}0.73^{* * *} \\
(0.1)\end{array}$ & $\begin{array}{c}0.78 * * * \\
(0.1)\end{array}$ & $\begin{array}{c}0.84^{* * *} \\
(0.2)\end{array}$ & $\begin{array}{c}0.84^{* * *} \\
(0.1)\end{array}$ & $\begin{array}{c}0.63^{* * *} \\
(0.2)\end{array}$ & $\begin{array}{c}0.88^{* * * *} \\
(0.1)\end{array}$ & & \\
\hline Dependency ratio & $\begin{array}{c}-0.033 \\
(0.1)\end{array}$ & $\begin{array}{l}0.15 \\
(0.1)\end{array}$ & $\begin{array}{l}0.047 \\
(0.2)\end{array}$ & $\begin{array}{c}0.088 \\
(0.1)\end{array}$ & $\begin{array}{l}0.10 \\
(0.1)\end{array}$ & $\begin{array}{l}0.070 \\
(0.2)\end{array}$ & $\begin{array}{c}0.039 \\
(0.1)\end{array}$ & $\begin{array}{l}0.099 \\
(0.2)\end{array}$ \\
\hline NFA & $\begin{array}{l}0.018 \\
(0.02)\end{array}$ & $\begin{array}{c}0.055^{* *} \\
(0.03)\end{array}$ & $\begin{array}{l}0.027 \\
(0.03)\end{array}$ & $\begin{array}{l}0.031 \\
(0.02)\end{array}$ & $\begin{array}{l}0.030 \\
(0.02)\end{array}$ & $\begin{array}{c}0.051^{*} \\
(0.03)\end{array}$ & $\begin{array}{c}-0.0011 \\
(0.02)\end{array}$ & $\begin{array}{c}-0.0093 \\
(0.03)\end{array}$ \\
\hline Terms of trade & $\begin{array}{l}1.66 \\
(3.5)\end{array}$ & $\begin{array}{c}7.50 * * \\
(3.0)\end{array}$ & & $\begin{array}{c}6.40 * * \\
(2.6)\end{array}$ & $\begin{array}{c}10.7 * * * \\
(3.4)\end{array}$ & $\begin{array}{c}7.79 * * * \\
(2.9)\end{array}$ & $\begin{array}{c}8.69 * * * \\
(2.9)\end{array}$ & $\begin{array}{c}14.9 * * * \\
(4.2)\end{array}$ \\
\hline Economic growth & $\begin{array}{l}-0.044 \\
(0.06)\end{array}$ & $\begin{array}{l}-0.025 \\
(0.07)\end{array}$ & $\begin{array}{l}-0.048 \\
(0.06)\end{array}$ & $\begin{array}{l}-0.025 \\
(0.06)\end{array}$ & $\begin{array}{l}0.056 \\
(0.08)\end{array}$ & $\begin{array}{l}-0.038 \\
(0.06)\end{array}$ & $\begin{array}{l}-0.024 \\
(0.05)\end{array}$ & $\begin{array}{l}0.020 \\
(0.08)\end{array}$ \\
\hline Relative income & $\begin{array}{l}-0.027 \\
(0.07)\end{array}$ & $\begin{array}{l}-0.018 \\
(0.07)\end{array}$ & $\begin{array}{l}-0.050 \\
(0.07)\end{array}$ & $\begin{array}{l}-0.034 \\
(0.06)\end{array}$ & $\begin{array}{l}-0.043 \\
(0.07)\end{array}$ & $\begin{array}{l}-0.10 \\
(0.07)\end{array}$ & $\begin{array}{l}0.073 \\
(0.06)\end{array}$ & $\begin{array}{l}0.14^{*} \\
(0.07)\end{array}$ \\
\hline REER & $\begin{array}{l}3.83 \\
(4.3)\end{array}$ & $\begin{array}{l}-4.28 \\
(4.3)\end{array}$ & $\begin{array}{l}-3.11 \\
(4.1)\end{array}$ & $\begin{array}{l}-3.67 \\
(3.4)\end{array}$ & $\begin{array}{l}-2.88 \\
(4.3)\end{array}$ & & $\begin{array}{c}-8.29 * * * \\
(3.2)\end{array}$ & $\begin{array}{c}-13.1^{* * * *} \\
(4.2)\end{array}$ \\
\hline Trade openness & $\begin{array}{l}0.022 \\
(0.04)\end{array}$ & $\begin{array}{l}0.031 \\
(0.05)\end{array}$ & $\begin{array}{l}0.053 \\
(0.05)\end{array}$ & $\begin{array}{l}0.047 \\
(0.04)\end{array}$ & $\begin{array}{c}-0.0018 \\
(0.06)\end{array}$ & $\begin{array}{l}0.072 \\
(0.05)\end{array}$ & $\begin{array}{l}-0.039 \\
(0.04)\end{array}$ & $\begin{array}{c}0.0081 \\
(0.08)\end{array}$ \\
\hline G7 growth & $\begin{array}{c}-6.11 * * \\
(2.9)\end{array}$ & $\begin{array}{c}1.19 * * * \\
(0.3)\end{array}$ & $\begin{array}{c}0.93^{* * *} \\
(0.3)\end{array}$ & $\begin{array}{c}1.11^{* * *} \\
(0.3)\end{array}$ & $\begin{array}{c}1.17 * * * \\
(0.4)\end{array}$ & $\begin{array}{c}0.98^{* * *} \\
(0.3)\end{array}$ & $\begin{array}{c}1.19^{* * *} \\
(0.3)\end{array}$ & $\begin{array}{c}1.57^{* * *} \\
(0.4)\end{array}$ \\
\hline G7 interest rate & $\begin{array}{l}-1.54 \\
(1.1)\end{array}$ & $\begin{array}{l}0.76 \\
(0.7)\end{array}$ & $\begin{array}{l}1.07^{*} \\
(0.6)\end{array}$ & $\begin{array}{l}0.83 \\
(0.5)\end{array}$ & $\begin{array}{c}-0.075 \\
(0.4)\end{array}$ & $\begin{array}{l}0.74 \\
(0.7)\end{array}$ & $\begin{array}{l}0.86 \\
(0.5)\end{array}$ & $\begin{array}{l}0.47 \\
(0.8)\end{array}$ \\
\hline Expenditure & & & & & & & $\begin{array}{c}-0.77 * * * \\
(0.2)\end{array}$ & $\begin{array}{c}-0.47 * * * \\
(0.2)\end{array}$ \\
\hline Revenue & & & & & & & $\begin{array}{c}0.82^{* * *} \\
(0.1)\end{array}$ & \\
\hline Gross FDI & & & & & $\begin{array}{l}-0.17 \\
(0.1)\end{array}$ & & & \\
\hline Oil price volatility & & & & $\begin{array}{l}0.34 \\
(0.3)\end{array}$ & & & & \\
\hline Oil price & & & $\begin{array}{l}5.09 * \\
(2.8)\end{array}$ & & & & & \\
\hline Credit & & $\begin{array}{c}-0.19 * \\
(0.10)\end{array}$ & & & & & & \\
\hline Constant & $\begin{array}{c}-11.8 \\
(15) \\
\end{array}$ & $\begin{array}{c}-21.4 \\
(26) \\
\end{array}$ & $\begin{array}{c}-9.25 \\
(21) \\
\end{array}$ & $\begin{array}{c}-22.4 \\
(19) \\
\end{array}$ & $\begin{array}{c}-38.3^{* * *} \\
(18) \\
\end{array}$ & $\begin{array}{c}-42.5^{* *} \\
(18) \\
\end{array}$ & $\begin{array}{c}-5.42 \\
(19) \\
\end{array}$ & $\begin{array}{c}-3.93 \\
(28) \\
\end{array}$ \\
\hline Fiscal balance (long-term) & $\begin{array}{c}1.90^{* *} \\
(0.8)\end{array}$ & $\begin{array}{c}1.21 * * * \\
(0.3)\end{array}$ & $\begin{array}{c}1.42^{* * *} \\
(0.4)\end{array}$ & $\begin{array}{c}1.43^{* * *} \\
(0.4)\end{array}$ & $\begin{array}{c}0.96 * * * \\
(0.3)\end{array}$ & $\begin{array}{c}1.45^{* * *} \\
(0.3)\end{array}$ & & \\
\hline Time dummies & Yes & No & No & No & No & No & No & No \\
\hline m1 (p-value) & 0.0076 & 0.0082 & 0.011 & 0.014 & 0.0096 & 0.016 & 0.017 & 0.0037 \\
\hline m2 (p-value) & 0.81 & 0.78 & 0.49 & 0.71 & 0.29 & 0.45 & 0.77 & 0.50 \\
\hline J-test ( $p$-value) & 1 & 0.37 & 0.034 & 0.37 & 0.24 & 0.11 & 0.67 & 0.44 \\
\hline Observations & 399 & 396 & 399 & 399 & 316 & 402 & 399 & 399 \\
\hline Number of countries & 21 & 21 & 21 & 21 & 21 & 21 & 21 & 21 \\
\hline
\end{tabular}

Notes: Robust standard errors in parentheses.

*** significant at $1 \%$; ** significant at $5 \%$; * significant at $10 \%$.

The sample excludes outliers. Time dummies are not shown.

Instruments for GMM-Sys: First lags of regressors; relative income and REER are lagged twice.

For oil exporters, $\mathrm{G} 7$ growth and interest rate instruments use contemporaneous values.

m1: Test for 1st order serial correlation in differences. m2: Test for 2nd order serial correlation in differences.

J-test: Test for overidentifying restrictions. 
Table 3. Current Account Estimations (1980-2007, 4-year average)

\begin{tabular}{|c|c|c|c|c|c|c|}
\hline & \multicolumn{2}{|c|}{ Pooled OLS } & \multicolumn{2}{|c|}{ Fixed effects } & \multicolumn{2}{|c|}{ GMM-Sys } \\
\hline & Global & $\begin{array}{c}\text { Oil } \\
\text { exporters }\end{array}$ & Global & $\begin{array}{c}\text { Oil } \\
\text { exporters }\end{array}$ & Global & $\begin{array}{c}\text { Oil } \\
\text { exporters }\end{array}$ \\
\hline Lagged current account & $\begin{array}{c}0.60 * * * \\
(0.05)\end{array}$ & $\begin{array}{c}0.23^{* * *} \\
(0.06)\end{array}$ & $\begin{array}{c}0.22 * * * \\
(0.06)\end{array}$ & $\begin{array}{l}0.13 * * \\
(0.06)\end{array}$ & $\begin{array}{c}0.49^{* * *} \\
(0.09)\end{array}$ & $\begin{array}{c}0.13^{* * *} \\
(0.04)\end{array}$ \\
\hline Fiscal balance & $\begin{array}{l}0.11^{* *} \\
(0.05)\end{array}$ & $\begin{array}{c}0.66^{* * *} \\
(0.1)\end{array}$ & $\begin{array}{l}0.063 \\
(0.06)\end{array}$ & $\begin{array}{c}0.68 * * * \\
(0.1)\end{array}$ & $\begin{array}{c}0.23^{*} \\
(0.1)\end{array}$ & $\begin{array}{c}0.58^{* * * *} \\
(0.2)\end{array}$ \\
\hline Dependency ratio & $\begin{array}{l}-0.011 \\
(0.01)\end{array}$ & $\begin{array}{l}0.010 \\
(0.05)\end{array}$ & $\begin{array}{l}-0.055 \\
(0.04)\end{array}$ & $\begin{array}{l}0.066 \\
(0.08)\end{array}$ & $\begin{array}{l}-0.040 \\
(0.07)\end{array}$ & $\begin{array}{l}-0.047 \\
(0.08)\end{array}$ \\
\hline NFA & $\begin{array}{c}0.012^{* * *} \\
(0.004)\end{array}$ & $\begin{array}{c}0.024^{* * *} \\
(0.007)\end{array}$ & $\begin{array}{l}-0.0074 \\
(0.007)\end{array}$ & $\begin{array}{l}0.020^{*} \\
(0.01)\end{array}$ & $\begin{array}{l}0.0013 \\
(0.02)\end{array}$ & $\begin{array}{c}0.020 * * * \\
(0.008)\end{array}$ \\
\hline Terms of trade & $\begin{array}{l}1.19 * * \\
(0.6)\end{array}$ & $\begin{array}{l}1.43 \\
(1.5)\end{array}$ & $\begin{array}{c}2.56^{* * *} \\
(0.7)\end{array}$ & $\begin{array}{l}3.40 * \\
(1.9)\end{array}$ & $\begin{array}{l}6.21^{* *} \\
(3.2)\end{array}$ & $\begin{array}{l}1.83 \\
(2.0)\end{array}$ \\
\hline Economic growth & $\begin{array}{l}-0.11^{*} \\
(0.06)\end{array}$ & $\begin{array}{l}-0.28^{*} \\
(0.2)\end{array}$ & $\begin{array}{c}-0.19 * * \\
(0.07)\end{array}$ & $\begin{array}{c}-0.073 \\
(0.1)\end{array}$ & $\begin{array}{l}-0.10 \\
(0.1)\end{array}$ & $\begin{array}{l}-0.067 \\
(0.2)\end{array}$ \\
\hline Relative income & $\begin{array}{l}0.0045 \\
(0.007)\end{array}$ & $\begin{array}{l}0.0032 \\
(0.02)\end{array}$ & $\begin{array}{c}-0.11^{* *} \\
(0.04)\end{array}$ & $\begin{array}{l}-0.14^{*} \\
(0.07)\end{array}$ & $\begin{array}{l}-0.021 \\
(0.03)\end{array}$ & $\begin{array}{l}0.051 \\
(0.04)\end{array}$ \\
\hline REER & $\begin{array}{c}-1.68^{* * * *} \\
(0.5)\end{array}$ & $\begin{array}{l}-2.38^{*} \\
(1.3)\end{array}$ & $\begin{array}{l}-2.20 * * * \\
(0.7)\end{array}$ & $\begin{array}{l}-2.75^{*} \\
(1.5)\end{array}$ & $\begin{array}{l}-4.80 \\
(3.7)\end{array}$ & $\begin{array}{l}-1.50 \\
(3.1)\end{array}$ \\
\hline Trade openness & $\begin{array}{c}0.0070^{*} \\
(0.004)\end{array}$ & $\begin{array}{c}-0.052^{* * *} \\
(0.01)\end{array}$ & $\begin{array}{c}0.0063 \\
(0.01)\end{array}$ & $\begin{array}{l}-0.053 \\
(0.05)\end{array}$ & $\begin{array}{l}0.0093 \\
(0.02)\end{array}$ & $\begin{array}{c}-0.067 * * \\
(0.03)\end{array}$ \\
\hline G7 growth & $\begin{array}{c}0.063 \\
(0.3)\end{array}$ & $\begin{array}{l}0.81 \\
(1.3)\end{array}$ & $\begin{array}{c}0.062 \\
(0.3)\end{array}$ & $\begin{array}{l}1.22 \\
(1.2)\end{array}$ & $\begin{array}{c}-0.056 \\
(0.4)\end{array}$ & $\begin{array}{l}0.44 \\
(1.2)\end{array}$ \\
\hline G7 interest rate & $\begin{array}{c}0.33^{* *} \\
(0.2)\end{array}$ & $\begin{array}{c}-1.78^{* * * *} \\
(0.7)\end{array}$ & $\begin{array}{c}0.073 \\
(0.2)\end{array}$ & $\begin{array}{c}-1.47^{*} \\
(0.7)\end{array}$ & $\begin{array}{c}0.61^{* *} \\
(0.3)\end{array}$ & $\begin{array}{c}-1.49 * * \\
(0.7)\end{array}$ \\
\hline Constant & $\begin{array}{l}1.78 \\
(3.5) \\
\end{array}$ & $\begin{array}{l}13.4^{*} \\
(7.7) \\
\end{array}$ & $\begin{array}{l}2.55 \\
(5.1) \\
\end{array}$ & $\begin{array}{l}6.69 \\
(14) \\
\end{array}$ & $\begin{array}{l}-5.53 \\
(11) \\
\end{array}$ & $\begin{array}{l}10.4 \\
(15) \\
\end{array}$ \\
\hline Fiscal balance (long-term) & $\begin{array}{c}0.27^{* *} \\
(0.1)\end{array}$ & $\begin{array}{c}0.85^{* * *} \\
(0.1)\end{array}$ & $\begin{array}{l}0.080 \\
(0.07)\end{array}$ & $\begin{array}{c}0.79 * * * \\
(0.2)\end{array}$ & $\begin{array}{c}0.45^{*} \\
(0.2)\end{array}$ & $\begin{array}{c}0.67^{* * * *} \\
(0.2)\end{array}$ \\
\hline $\mathrm{R}^{2}$ & 0.53 & 0.86 & 0.13 & 0.78 & & \\
\hline Adjusted $\mathrm{R}^{2}$ & 0.52 & 0.84 & 0.11 & 0.75 & & \\
\hline m1 (p-value) & & & & & 0.00 & 0.11 \\
\hline m2 (p-value) & & & & & 0.03 & 0.78 \\
\hline J-test (p-value) & & & & & 0.09 & 0.25 \\
\hline $\begin{array}{l}\text { Observations } \\
\text { Number of countries }\end{array}$ & 555 & 91 & $\begin{array}{l}555 \\
114\end{array}$ & $\begin{array}{l}91 \\
20\end{array}$ & $\begin{array}{l}555 \\
114\end{array}$ & $\begin{array}{l}91 \\
20\end{array}$ \\
\hline
\end{tabular}

Notes: Robust standard errors in parentheses.

*** significant at $1 \%$; ** significant at $5 \%$; * significant at $10 \%$.

The sample excludes outliers.

Instruments for GMM-Sys: First lags of regressors; relative income and REER are lagged twice.

For oil exporters, G7 growth and interest rate instruments use contemporaneous values.

$\mathrm{m} 1$ : Test for 1st order serial correlation in differences.

$\mathrm{m} 2$ : Test for 2nd order serial correlation in differences. J-test: Test for overidentifying restrictions. 


\section{CONCLUDING REMARKS}

We explore the role played by oil-exporting countries in global imbalances. Oil exporters have recently amassed large sums of petrodollars joining a group of large CA surplus countries. The impact of oil exporters' policies on global imbalances is thus of great importance. As the oil price has fallen from its peak in the summer 2008 and the current financial crisis takes its toll on global economic growth, eventually, the world economy would recover and oil prices would rise again, widening existing imbalances. Yet we contend that it is not only the oil price that is relevant for the current account dynamics of oilexporting countries. Fiscal policy is a major determinant while controlling for the oil price or terms of trade and correcting for endogeneity. We find that expenditures still matter, conditioning on revenues.

With a faster adjustment of current account and a stronger effect of fiscal policy, oilexporting countries play an important role in the evolution of global imbalances. For instance, if oil exporters reduced their public saving by 1 percent of GDP in 2007, it would have lowered their overall external balance by about 7 percent, reducing global imbalances by about $\$ 32$ billion. It is noteworthy to emphasize that the fiscal expansion during an oil boom could both exacerbate macroeconomic volatility and Dutch disease effects if expenditures are oriented toward nontradable goods. ${ }^{17}$

We find that appreciation of the real exchange rate in oil-exporting countries is unlikely to have significant impact on their external balances. ${ }^{18}$ Indeed, the elasticity of the current account balance to the real exchange rate is not statistically significant using the GMM estimator. Even if an estimate were significant, it would require a large exchange rate movement to obtain a relatively small current account adjustment. ${ }^{19}$

In addition to fiscal policy, policy decisions of SWFs are likely to affect global imbalances. Use and investment of accumulated oil money in net foreign assets could either exacerbate or mitigate these imbalances. If funds are invested in US Treasuries, for instance, global imbalances may widen further. With long-term portfolio investments and FDI, there is a potential for the orderly unwinding of global imbalances as funds are channeled into productive purposes rather than current consumption. Where petrodollars flow is crucial and will be even more so in the future.

\footnotetext{
${ }^{17}$ However, domestic spending directed toward tradable goods and existing supply bottlenecks are likely to ease inflationary pressures. Expenditures that promote long-term growth and economic diversification may mitigate Dutch disease concerns as well.

${ }^{18}$ Billmeier and Hakura (2008) find that the impact of the REER on the trade balance is small using a sample of oil-exporting countries in the Middle East and Central Asia region.

${ }^{19}$ Real exchange rate appreciation in oil-exporting countries would also imply potentially large adverse balance sheet effects given large external asset positions of some oil-exporting countries.
} 


\section{References}

Arezki, Rabah, 2007, “GCC Current Account Determinants,” unpublished, International Monetary Fund, Washington, DC.

Arellano, Manuel and Stephen Bond, 1991, "Some Tests of Specification for Panel Data: Monte Carlo Evidence and an Application to Employment Equations," Review of Economic Studies, Vol. 58, pp. 277-97.

Bernanke, Ben S., 2005, “The Global Saving Glut and the U.S. Current Account,” Remarks at the Sandridge Lecture, Virginia Association of Economics, Richmond, VA, March 10 .

Besley, David A., Edwin Kuh, and Roy E. Welch, 1980, Regression Diagnostics: Identifying Influential Data and Source of Collinearity, John Wiley, New York.

Billmeier, Andreas and Dalia Hakura, 2008, "Trade Elasticities in the Middle East and Central Asia: What is the Role of Oil?” Working Paper No. 08/216, International Monetary Fund, Washington, DC.

Blundell, R.W., and S. Bond, 1998, “Initial Conditions and Moment Restrictions in Dynamic Panel Data Models,” Journal of Econometrics, Vol. 87, pp. 115-143.

Bond, Stephen, Anke Hoeffler and Jonathan Temple, 2001, "GMM Estimation of Empirical Growth Models,” Economics Papers 2001-W21, Economics Group, Nuffield College, University of Oxford.

Calderon, Cesar, Alberto Chong, and Norman Loayza, 2002, "Determinants of Current Account Deficits in Developing Countries," Contributions to Macroeconomics, Berkeley Electronic Press, Vol. 2(1), pp. 1021-1021.

Calderón, César, Alberto Chong and Luisa Zanforlin, 2007, “Current Account Deficits in Africa: Stylized Facts and Basic Determinants,” Economic Development and Cultural Change, Vol. 56, pp. 191-221 (University of Chicago Press).

Chinn, Menzie D. and Eswar S. Prasad, 2003, "Medium-Term Determinants of Current Accounts in Industrial and Developing Countries: An Empirical Exploration," Journal of International Economics, Elsevier, Vol. 59(1) (January), pp. 47-76.

Chinn, Menzie D. and Hiro Ito, 2007, “Current Account Balances, Financial Development and Institutions: Assaying the World 'Saving Glut,"” Journal of International Money and Finance, 26(4), pp. 546-569. 
Chinn, Menzie D. and Hiro Ito, 2008, “Global Current Account Imbalances: American Fiscal Policy versus East Asian Savings,” Review of International Economics, 16(3), pp. 479-498.

Clarida, R., 2005a, “Japan, China, and the U.S. Current Account Deficit,” CATO Journal 25(1).

Clarida, R., 2005b, “Some Thoughts on The Sustainability and Adjustment of Global Current Account Imbalances,” Speech at the Council on Foreign Relations, March 28.

Corsetti, Giancarlo and Gernot J. Müller, 2006, “Twin Deficits: Squaring Theory, Evidence and Common Sense,” Economic Policy, CEPR, CES, MSH, Vol. 21(48) (October), pp. 597-638.

Davidson, Russel, and James G. MacKinnon, 1993, Estimation and Inference in Econometrics, New York: Oxford University Press.

Edwards, Sebastian, 2007, “On Current Account Surpluses and the Correction of Global Imbalances,” NBER Working Paper No. 12904.

Faini, Riccardo, 1994, “Workers Remittances and the Real Exchange Rate: A Quantitative Framework,” Journal of Population Economics, Springer, Vol. 7(2), pp. 235-45.

Ferguson, R.W., 2004, “Global Imbalances,” Speech at European Institute Roundtable on Financial and Monetary Affairs, Washington, DC, April 23.

Greenspan, Alan, 2005a, “Current Account,” Advancing Enterprise 2005 Conference, London, England, February 4.

Greenspan, Alan, 2005b, “Mortgage Banking,” American Bankers Association Annual Convention, Palm Desert, California, September 26.

Gruber, J.W. and S.B. Kamin, 2007, "Explaining the Global Pattern of Current Account Imbalances,” Journal of International Money and Finance, 26(4), pp. 500-522.

Hasanov, F. and A. Senhadji, 2008, "Macroeconomic Balance Approach and Assessment of Exchange Rate Misalignments,” in “Assessment of Exchange Rates” Report, Middle East and Central Asia Department, International Monetary Fund, Washington, DC.

Higgins, Matthew, 1998, "Demography, National Savings and International Capital Flows," International Economic Review, Vol. 39, No. 2, pp. 343-69.

International Monetary Fund, 2008a, World Economic Outlook (WEO), October. 
International Monetary Fund, 2008b, World Economic Outlook(WEO), October, Chapter 6.

International Monetary Fund, 2008c, Information Notice System (INS).

Institute of International Finance, 2008, Economic and Capital Flow Database, October.

Milesi-Ferretti, Gian Maria and Philip R. Lane, 2006, “The External Wealth of Nations Mark II: Revised and Extended Estimates of Foreign Assets and Liabilities, 1970-2004,” IMF Working Paper 06/69, International Monetary Fund, Washington, DC.

World Bank Group, 2008, World Development Indicators (WDI). 


\section{Appendix I}

\section{Data Description and Sources}

\begin{tabular}{|c|c|c|c|}
\hline Database & Units & Descriptor & Variable \\
\hline WEO (2008) $1 /$ & Percent of GDP & Current account balance & Current account \\
\hline WEO (2008) & Percent of GDP & General government balance 2/ & Fiscal balance \\
\hline WDI (2008) & Percent & $\begin{array}{l}\text { Age dependency ratio (old and young share of working } \\
\text { age population) }\end{array}$ & Dependency ratio \\
\hline WEO (2008) & Index number & Natural logarithm of terms of trade of goods & Terms of trade \\
\hline $\begin{array}{l}\text { Lane and } \\
\text { Milesi-Ferretti (2006) 3/ }\end{array}$ & Percent of GDP & One period lagged net external asset position & NFA \\
\hline WEO (2008) & Percent & Real GDP per capita growth rate & Output growth \\
\hline WDI (2008) & Percent & Real PPP income per capita relative to that of the US & Relative income \\
\hline INS (2008) & Index number & Natural logarithm of real effective exchange rate & REER \\
\hline WDI (2008) & Percent of GDP & Sum of exports and imports & Trade openness \\
\hline WEO (2008) & Percent & G7 real GDP per capita growth & G7 growth \\
\hline WEO (2008) & Percent & G7 real short-term deposit rate & $\mathrm{G} 7$ interest rate \\
\hline WDI (2008) & Percent of GDP & Domestic credit to the private sector & Credit \\
\hline WEO (2008) & US dollars & $\begin{array}{l}\text { Natural logarithm of crude oil price, an average of three } \\
\text { spot prices } 4 /\end{array}$ & Oil price \\
\hline WEO (2008) & US dollars & Standard deviation of monthly oil prices & Oil price volatility \\
\hline WEO (2008) & Percent of GDP & Gross foreign direct investment & Gross FDI \\
\hline
\end{tabular}

1/ WEO: World Economic Outlook Database; WDI: World Development Indicators Database. INS: Information Notice System (IMF).

2/ Central government data are used when general government data are unavailable.

3/ We thank G.M. Milesi-Ferretti for providing updated data through 2006.

4/ The three spot prices are Dated Brent, West Texas Intermediate, and Dubai Fateh (USD per barrel). 


\section{Appendix II}

\section{GMM Estimators}

The estimated specification is as follows:

$$
c a_{i t}=\alpha_{0}+\alpha c a_{i t-1}+X_{i t} \beta+\mu_{i}+\varepsilon_{i t},
$$

where $c a_{i t}$ is the current account ratio for country $i$ and time $t ; X_{i t}$ is a vector of control variables as specified in the text; and $\mu_{i}$ is the country fixed effect. Equation (A1) is differenced to get rid of the country fixed effects and the instruments used are lagged levels of regressors:

$$
c a_{i t}-c a_{i t-1}=\alpha\left(c a_{i t-1}-c a_{i t-2}\right)+\left(X_{i t}-X_{i t-1}\right) \beta+\left(\varepsilon_{i t}-\varepsilon_{i t-1}\right)
$$

The moment conditions arising from equation (A2) are:

$$
E\left[\left(\varepsilon_{i t}-\varepsilon_{i t-1}\right) z_{i t-1}\right]=0,
$$

where $z_{i t-1}$ is the instrument set of lagged levels of regressors. The estimator based on (A3) is the GMM-Diff. The GMM-Sys estimator, which we use as our main estimator, in addition to moment conditions in (A3), uses additional moment conditions. These are equations in levels (equation A1) but with a weaker assumption than the country fixed effects are uncorrelated with differenced regressors (which amounts to a restriction on initial conditions):

$$
E\left[\left(\mu_{i}+\varepsilon_{i t}\right) \Delta z_{i t-1}\right]=0
$$

Now, the equation is specified in levels but the instruments, which are lagged levels of regressors, are differenced. 


\section{Appendix III}

Table A1. Current Account Estimations: Total Sample (With Outliers, 1980-2007, Annual)

\begin{tabular}{|c|c|c|c|c|c|c|}
\hline & \multicolumn{2}{|c|}{ Pooled OLS } & \multicolumn{2}{|c|}{ Fixed effects } & \multicolumn{2}{|c|}{ GMM-Sys } \\
\hline & Global & $\begin{array}{c}\text { Oil } \\
\text { exporters }\end{array}$ & Global & $\begin{array}{c}\text { Oil } \\
\text { exporters }\end{array}$ & Global & $\begin{array}{c}\text { Oil } \\
\text { exporters }\end{array}$ \\
\hline Lagged current account & $\begin{array}{c}0.75^{* * * *} \\
(0.04)\end{array}$ & $\begin{array}{c}0.50^{* * *} \\
(0.09)\end{array}$ & $\begin{array}{c}0.57^{* * *} \\
(0.04)\end{array}$ & $\begin{array}{c}0.27 * * \\
(0.1)\end{array}$ & $\begin{array}{c}0.75^{* * * *} \\
(0.07)\end{array}$ & $\begin{array}{c}0.42^{* * *} \\
(0.1)\end{array}$ \\
\hline Fiscal balance & $\begin{array}{c}0.13 * * * \\
(0.03)\end{array}$ & $\begin{array}{c}0.45^{* * * *} \\
(0.07)\end{array}$ & $\begin{array}{c}0.17 * * * \\
(0.03)\end{array}$ & $\begin{array}{c}0.59 * * * \\
(0.1)\end{array}$ & $\begin{array}{c}0.29 * * * \\
(0.07)\end{array}$ & $\begin{array}{c}0.71 * * * \\
(0.10)\end{array}$ \\
\hline Dependency ratio & $\begin{array}{l}-0.0078 \\
(0.008)\end{array}$ & $\begin{array}{l}0.030 \\
(0.04)\end{array}$ & $\begin{array}{c}-0.089 * * * \\
(0.02)\end{array}$ & $\begin{array}{l}-0.024 \\
(0.06)\end{array}$ & $\begin{array}{l}-0.098 \\
(0.07)\end{array}$ & $\begin{array}{l}0.31 \\
(0.3)\end{array}$ \\
\hline NFA & $\begin{array}{c}0.0083^{* * *} \\
(0.003)\end{array}$ & $\begin{array}{c}0.019^{* * *} \\
(0.007)\end{array}$ & $\begin{array}{l}0.0013 \\
(0.001)\end{array}$ & $\begin{array}{l}0.027 * \\
(0.02)\end{array}$ & $\begin{array}{l}-0.0018 \\
(0.004)\end{array}$ & $\begin{array}{l}0.0024 \\
(0.04)\end{array}$ \\
\hline Terms of trade & $\begin{array}{l}0.59 * \\
(0.3)\end{array}$ & $\begin{array}{l}2.67 * \\
(1.5)\end{array}$ & $\begin{array}{c}1.41 * * * \\
(0.5)\end{array}$ & $\begin{array}{c}6.91^{* * * *} \\
(1.9)\end{array}$ & $\begin{array}{c}12.3^{* * * *} \\
(3.2)\end{array}$ & $\begin{array}{c}18.3^{* * * *} \\
(3.3)\end{array}$ \\
\hline Economic growth & $\begin{array}{c}-0.11 * * * \\
(0.03)\end{array}$ & $\begin{array}{c}-0.0041 \\
(0.1)\end{array}$ & $\begin{array}{c}-0.12 * * * \\
(0.04)\end{array}$ & $\begin{array}{l}0.077 \\
(0.1)\end{array}$ & $\begin{array}{l}-0.12^{*} \\
(0.06)\end{array}$ & $\begin{array}{l}-0.032 \\
(0.07)\end{array}$ \\
\hline Relative income & $\begin{array}{l}0.0066 \\
(0.005)\end{array}$ & $\begin{array}{l}0.023 \\
(0.02)\end{array}$ & $\begin{array}{c}-0.062^{* *} \\
(0.03)\end{array}$ & $\begin{array}{c}0.074^{* *} \\
(0.03)\end{array}$ & $\begin{array}{l}-0.071 \\
(0.05)\end{array}$ & $\begin{array}{l}0.27^{*} \\
(0.2)\end{array}$ \\
\hline REER & $\begin{array}{c}-0.49 * \\
(0.3)\end{array}$ & $\begin{array}{c}-2.84^{* * * *} \\
(1.0)\end{array}$ & $\begin{array}{c}-1.21 * * * \\
(0.3)\end{array}$ & $\begin{array}{c}-4.63^{* * *} \\
(1.3)\end{array}$ & $\begin{array}{c}-4.41^{*} \\
(2.5)\end{array}$ & $\begin{array}{c}-9.15^{*} \\
(5.5)\end{array}$ \\
\hline Trade openness & $\begin{array}{l}0.0029 \\
(0.002)\end{array}$ & $\begin{array}{c}-0.065^{* *} \\
(0.03)\end{array}$ & $\begin{array}{l}-0.016 \\
(0.01)\end{array}$ & $\begin{array}{c}-0.17^{* * *} \\
(0.06)\end{array}$ & $\begin{array}{l}-0.055 \\
(0.04)\end{array}$ & $\begin{array}{c}-0.34^{* * *} \\
(0.1)\end{array}$ \\
\hline G7 growth & $\begin{array}{l}0.15^{*} \\
(0.08)\end{array}$ & $\begin{array}{c}1.60^{* * *} \\
(0.4)\end{array}$ & $\begin{array}{l}0.16^{* *} \\
(0.08)\end{array}$ & $\begin{array}{c}0.99 * * \\
(0.4)\end{array}$ & $\begin{array}{l}0.30 * \\
(0.2)\end{array}$ & $\begin{array}{c}2.43^{* * *} \\
(0.8)\end{array}$ \\
\hline G7 interest rate & $\begin{array}{l}-0.019 \\
(0.07)\end{array}$ & $\begin{array}{l}-0.23 \\
(0.4)\end{array}$ & $\begin{array}{l}0.010 \\
(0.07)\end{array}$ & $\begin{array}{l}0.41 \\
(0.4)\end{array}$ & $\begin{array}{l}-0.11 \\
(0.2)\end{array}$ & $\begin{array}{l}-1.19 \\
(2.0)\end{array}$ \\
\hline Constant & $\begin{array}{r}-0.20 \\
(2.0) \\
\end{array}$ & $\begin{array}{l}3.02 \\
(7.2) \\
\end{array}$ & $\begin{array}{c}7.40^{* *} \\
(3.7) \\
\end{array}$ & $\begin{array}{l}3.12 \\
(12) \\
\end{array}$ & $\begin{array}{l}-24.2 \\
(19) \\
\end{array}$ & $\begin{array}{l}-41.5 \\
(39) \\
\end{array}$ \\
\hline Fiscal balance (long-term) & $\begin{array}{c}0.52^{* * *} \\
(0.1)\end{array}$ & $\begin{array}{c}0.91^{* * *} \\
(0.1)\end{array}$ & $\begin{array}{c}0.39 * * * \\
(0.09)\end{array}$ & $\begin{array}{c}0.81^{* * *} \\
(0.2)\end{array}$ & $\begin{array}{c}1.15^{* *} \\
(0.5)\end{array}$ & $\begin{array}{c}1.24^{* * *} \\
(0.4)\end{array}$ \\
\hline $\mathrm{R}^{2}$ & 0.71 & 0.61 & 0.42 & 0.48 & & \\
\hline Adjusted $\mathrm{R}^{2}$ & 0.71 & 0.60 & 0.42 & 0.46 & & \\
\hline m1 (p-value) & & & & & 0.00 & 0.09 \\
\hline m2 (p-value) & & & & & 0.93 & 0.83 \\
\hline J-test (p-value) & & & & & 0.09 & 0.47 \\
\hline Observations & 2505 & 430 & 2505 & 430 & 2505 & 430 \\
\hline Number of countries & & & 115 & 21 & 115 & 21 \\
\hline
\end{tabular}

Notes: Robust standard errors in parentheses.

*** significant at $1 \%$; ** significant at $5 \%$; * significant at $10 \%$. Instruments for GMM-Sys: First lags of regressors; relative income and REER are lagged twice

For oil exporters, G7 growth and interest rate instruments use contemporaneous values. $\mathrm{m1}$ : Test for 1st order serial correlation in differences.

$\mathrm{m} 2$ : Test for 2 nd order serial correlation in differences. J-test: Test for overidentifying restrictions. 
Table A2. Current Account Estimations: Oil Exporters, Pooled OLS (1980-2007, Annual)

\begin{tabular}{|c|c|c|c|c|c|c|c|c|}
\hline Lagged current account & $\begin{array}{c}0.60 * * * \\
(0.05)\end{array}$ & $\begin{array}{c}0.49 * * * \\
(0.05)\end{array}$ & $\begin{array}{c}0.50 * * * \\
(0.05)\end{array}$ & $\begin{array}{c}0.52 * * * \\
(0.04)\end{array}$ & $\begin{array}{c}0.47^{* * *} \\
(0.05)\end{array}$ & $\begin{array}{c}0.51^{* * *} \\
(0.04)\end{array}$ & $\begin{array}{c}0.52^{* * *} \\
(0.05)\end{array}$ & $\begin{array}{c}0.68 * * * \\
(0.04)\end{array}$ \\
\hline Fiscal balance & $\begin{array}{c}0.36 * * * \\
(0.05)\end{array}$ & $\begin{array}{c}0.52^{* * *} \\
(0.05)\end{array}$ & $\begin{array}{c}0.44^{* * *} \\
(0.05)\end{array}$ & $\begin{array}{c}0.45^{* * *} \\
(0.05)\end{array}$ & $\begin{array}{c}0.48^{* * *} \\
(0.07)\end{array}$ & $\begin{array}{c}0.50 * * * \\
(0.05)\end{array}$ & & \\
\hline Dependency ratio & $\begin{array}{c}0.053^{*} \\
(0.03)\end{array}$ & $\begin{array}{c}0.053^{*} \\
(0.03)\end{array}$ & $\begin{array}{l}0.031 \\
(0.03)\end{array}$ & $\begin{array}{c}0.064^{* *} \\
(0.03)\end{array}$ & $\begin{array}{c}0.065 * * \\
(0.03)\end{array}$ & $\begin{array}{l}0.029 \\
(0.03)\end{array}$ & $\begin{array}{c}0.061^{* *} \\
(0.03)\end{array}$ & $\begin{array}{c}0.082^{* * *} \\
(0.03)\end{array}$ \\
\hline NFA & $\begin{array}{c}0.012^{* *} \\
(0.005)\end{array}$ & $\begin{array}{c}0.019 * * * \\
(0.005)\end{array}$ & $\begin{array}{c}0.013^{* * *} \\
(0.005)\end{array}$ & $\begin{array}{c}0.015^{* * *} \\
(0.005)\end{array}$ & $\begin{array}{c}0.016^{* * * *} \\
(0.005)\end{array}$ & $\begin{array}{c}0.014^{* * *} \\
(0.005)\end{array}$ & $\begin{array}{c}0.016^{* * *} \\
(0.005)\end{array}$ & $\begin{array}{c}0.011^{* *} \\
(0.005)\end{array}$ \\
\hline Terms of trade & $\begin{array}{c}2.07^{* *} \\
(0.9)\end{array}$ & $\begin{array}{c}3.21^{* * *} \\
(0.9)\end{array}$ & & $\begin{array}{c}2.99 * * * \\
(0.8)\end{array}$ & $\begin{array}{c}5.09 * * * \\
(1.2)\end{array}$ & $\begin{array}{c}2.54^{* * *} \\
(0.8)\end{array}$ & $\begin{array}{c}3.43^{* * *} \\
(0.9)\end{array}$ & $\begin{array}{c}4.39 * * * \\
(1.0)\end{array}$ \\
\hline Economic growth & $\begin{array}{l}-0.049 \\
(0.06)\end{array}$ & $\begin{array}{l}-0.036 \\
(0.06)\end{array}$ & $\begin{array}{l}-0.051 \\
(0.06)\end{array}$ & $\begin{array}{l}-0.049 \\
(0.06)\end{array}$ & $\begin{array}{l}-0.045 \\
(0.07)\end{array}$ & $\begin{array}{l}-0.025 \\
(0.06)\end{array}$ & $\begin{array}{l}-0.033 \\
(0.06)\end{array}$ & $\begin{array}{l}0.033 \\
(0.08)\end{array}$ \\
\hline Relative income & $\begin{array}{l}0.017 \\
(0.01)\end{array}$ & $\begin{array}{c}0.036 * * \\
(0.01)\end{array}$ & $\begin{array}{c}0.0087 \\
(0.01)\end{array}$ & $\begin{array}{l}0.014 \\
(0.01)\end{array}$ & $\begin{array}{c}0.0033 \\
(0.01)\end{array}$ & $\begin{array}{l}0.0090 \\
(0.01)\end{array}$ & $\begin{array}{c}0.0089 \\
(0.01)\end{array}$ & $\begin{array}{c}0.055 * * * \\
(0.01)\end{array}$ \\
\hline REER & $\begin{array}{c}-1.32 * \\
(0.8)\end{array}$ & $\begin{array}{c}-2.24 * * * \\
(0.7)\end{array}$ & $\begin{array}{c}-2.60 * * * \\
(0.8)\end{array}$ & $\begin{array}{c}-2.37 * * * \\
(0.7)\end{array}$ & $\begin{array}{c}-2.52 * * * \\
(0.9)\end{array}$ & & $\begin{array}{c}-2.45^{* * *} \\
(0.7)\end{array}$ & $\begin{array}{c}-3.01^{* * *} \\
(0.9)\end{array}$ \\
\hline Trade openness & $\begin{array}{c}-0.023^{* *} \\
(0.010)\end{array}$ & $\begin{array}{c}-0.031^{* * *} \\
(0.01)\end{array}$ & $\begin{array}{c}-0.028^{* * *} \\
(0.01)\end{array}$ & $\begin{array}{c}-0.024^{* *} \\
(0.010)\end{array}$ & $\begin{array}{c}-0.0097 \\
(0.01)\end{array}$ & $\begin{array}{c}-0.019 * \\
(0.010)\end{array}$ & $\begin{array}{c}-0.023^{* *} \\
(0.010)\end{array}$ & $\begin{array}{c}-0.020^{*} \\
(0.01)\end{array}$ \\
\hline G7 growth & $\begin{array}{c}1.17^{* *} \\
(0.5)\end{array}$ & $\begin{array}{c}1.53^{* * * *} \\
(0.3)\end{array}$ & $\begin{array}{c}1.40^{* * * *} \\
(0.3)\end{array}$ & $\begin{array}{c}1.51 * * * \\
(0.3)\end{array}$ & $\begin{array}{c}1.51^{* * *} \\
(0.4)\end{array}$ & $\begin{array}{c}1.46^{* * *} \\
(0.3)\end{array}$ & $\begin{array}{c}1.55^{* * *} \\
(0.3)\end{array}$ & $\begin{array}{c}1.99 * * * \\
(0.3)\end{array}$ \\
\hline G7 interest rate & $\begin{array}{l}-0.30 \\
(0.4)\end{array}$ & $\begin{array}{l}-0.24 \\
(0.3)\end{array}$ & $\begin{array}{c}-0.013 \\
(0.3)\end{array}$ & $\begin{array}{l}-0.17 \\
(0.3)\end{array}$ & $\begin{array}{c}-0.58^{*} \\
(0.3)\end{array}$ & $\begin{array}{c}-0.47^{*} \\
(0.3)\end{array}$ & $\begin{array}{l}-0.39 \\
(0.3)\end{array}$ & $\begin{array}{c}-1.16^{* * *} \\
(0.3)\end{array}$ \\
\hline Expenditure & & & & & & & $\begin{array}{c}-0.48^{* * *} \\
(0.06)\end{array}$ & $\begin{array}{c}-0.11^{* * *} \\
(0.04)\end{array}$ \\
\hline Revenue & & & & & & & $\begin{array}{c}0.48 * * * \\
(0.05)\end{array}$ & \\
\hline Gross FDI & & & & & $\begin{array}{l}-0.15 \\
(0.1)\end{array}$ & & & \\
\hline Oil price volatility & & & & $\begin{array}{c}0.69 * * * \\
(0.2)\end{array}$ & & & & \\
\hline Oil price & & & $\begin{array}{c}4.55^{* * *} \\
(1.1)\end{array}$ & & & & & \\
\hline Credit & & $\begin{array}{c}-0.077 * * * \\
(0.02)\end{array}$ & & & & & & \\
\hline Constant & $\begin{array}{l}-6.04 \\
(6.0) \\
\end{array}$ & $\begin{array}{r}-4.44 \\
(5.3) \\
\end{array}$ & $\begin{array}{r}-3.11 \\
(4.4) \\
\end{array}$ & $\begin{array}{l}-7.54 \\
(5.0) \\
\end{array}$ & $\begin{array}{c}-13.5^{* *} \\
(6.0) \\
\end{array}$ & $\begin{array}{c}-12.1 * * \\
(4.8) \\
\end{array}$ & $\begin{array}{r}-6.58 \\
(5.4) \\
\end{array}$ & $\begin{array}{l}-7.38 \\
(5.9) \\
\end{array}$ \\
\hline Fiscal balance (long-term) & $\begin{array}{c}0.90^{* * *} \\
(0.1)\end{array}$ & $\begin{array}{c}1.01^{* * *} \\
(0.08)\end{array}$ & $\begin{array}{c}0.88^{* * *} \\
(0.10)\end{array}$ & $\begin{array}{c}0.94^{* * *} \\
(0.09)\end{array}$ & $\begin{array}{c}0.91^{* * *} \\
(0.1)\end{array}$ & $\begin{array}{c}1.02^{* * *} \\
(0.09)\end{array}$ & & \\
\hline Time dummies & Yes & No & No & No & No & No & No & No \\
\hline $\mathrm{R}^{2}$ & 0.78 & 0.74 & 0.73 & 0.74 & 0.72 & 0.72 & 0.73 & 0.66 \\
\hline Adjusted $\mathrm{R}^{2}$ & 0.76 & 0.73 & 0.73 & 0.73 & 0.70 & 0.72 & 0.72 & 0.65 \\
\hline Observations & 399 & 396 & 399 & 399 & 316 & 402 & 399 & 399 \\
\hline
\end{tabular}

Notes: Robust standard errors in parentheses.

*** significant at $1 \%$; ** significant at $5 \%$; * significant at $10 \%$.

The sample excludes outliers. Time dummies are not shown. 
Table A3. Current Account Estimations: Oil Exporters, FE (1980-2007, Annual)

\begin{tabular}{|c|c|c|c|c|c|c|c|c|}
\hline Lagged current account & $\begin{array}{c}0.45^{* * *} \\
(0.05)\end{array}$ & $\begin{array}{c}0.35^{* * *} \\
(0.05)\end{array}$ & $\begin{array}{c}0.37 * * * \\
(0.05)\end{array}$ & $\begin{array}{c}0.37 * * * \\
(0.05)\end{array}$ & $\begin{array}{c}0.31^{* * *} \\
(0.06)\end{array}$ & $\begin{array}{c}0.36 * * * \\
(0.05)\end{array}$ & $\begin{array}{c}0.35^{* * *} \\
(0.05)\end{array}$ & $\begin{array}{c}0.51 * * * \\
(0.05)\end{array}$ \\
\hline Fiscal balance & $\begin{array}{c}0.45^{* * *} \\
(0.06)\end{array}$ & $\begin{array}{c}0.59 * * * \\
(0.06)\end{array}$ & $\begin{array}{c}0.52^{* * *} \\
(0.06)\end{array}$ & $\begin{array}{c}0.54 * * * \\
(0.06)\end{array}$ & $\begin{array}{c}0.54 * * * \\
(0.08)\end{array}$ & $\begin{array}{c}0.60 * * * \\
(0.06)\end{array}$ & & \\
\hline Dependency ratio & $\begin{array}{l}0.035 \\
(0.05)\end{array}$ & $\begin{array}{l}0.037 \\
(0.05)\end{array}$ & $\begin{array}{l}0.041 \\
(0.05)\end{array}$ & $\begin{array}{l}0.055 \\
(0.05)\end{array}$ & $\begin{array}{l}-0.031 \\
(0.08)\end{array}$ & $\begin{array}{l}-0.037 \\
(0.04)\end{array}$ & $\begin{array}{l}0.020 \\
(0.05)\end{array}$ & $\begin{array}{l}0.075 \\
(0.06)\end{array}$ \\
\hline NFA & $\begin{array}{c}0.011 \\
(0.009)\end{array}$ & $\begin{array}{l}0.016 * \\
(0.009)\end{array}$ & $\begin{array}{l}0.0042 \\
(0.009)\end{array}$ & $\begin{array}{c}0.012 \\
(0.008)\end{array}$ & $\begin{array}{c}0.029 * * \\
(0.01)\end{array}$ & $\begin{array}{l}0.0089 \\
(0.009)\end{array}$ & $\begin{array}{c}0.014 \\
(0.008)\end{array}$ & $\begin{array}{l}0.0039 \\
(0.009)\end{array}$ \\
\hline Terms of trade & $\begin{array}{c}3.08 * * * \\
(1.1)\end{array}$ & $\begin{array}{c}5.32^{* * *} \\
(1.0)\end{array}$ & & $\begin{array}{c}5.16^{* * *} \\
(1.0)\end{array}$ & $\begin{array}{c}6.47 * * * \\
(1.4)\end{array}$ & $\begin{array}{c}4.22 * * * \\
(1.0)\end{array}$ & $\begin{array}{c}5.57 * * * \\
(1.0)\end{array}$ & $\begin{array}{c}7.65^{* * *} \\
(1.2)\end{array}$ \\
\hline Economic growth & $\begin{array}{c}-0.0043 \\
(0.06)\end{array}$ & $\begin{array}{l}0.022 \\
(0.06)\end{array}$ & $\begin{array}{c}-0.0040 \\
(0.06)\end{array}$ & $\begin{array}{c}0.0090 \\
(0.06)\end{array}$ & $\begin{array}{l}0.011 \\
(0.07)\end{array}$ & $\begin{array}{l}0.032 \\
(0.06)\end{array}$ & $\begin{array}{l}0.024 \\
(0.06)\end{array}$ & $\begin{array}{l}0.066 \\
(0.07)\end{array}$ \\
\hline Relative income & $\begin{array}{c}0.0075 \\
(0.03)\end{array}$ & $\begin{array}{l}0.010 \\
(0.03)\end{array}$ & $\begin{array}{l}-0.019 \\
(0.03)\end{array}$ & $\begin{array}{l}0.021 \\
(0.03)\end{array}$ & $\begin{array}{l}-0.014 \\
(0.08)\end{array}$ & $\begin{array}{l}0.013 \\
(0.03)\end{array}$ & $\begin{array}{l}0.017 \\
(0.03)\end{array}$ & $\begin{array}{l}0.030 \\
(0.03)\end{array}$ \\
\hline REER & $\begin{array}{c}-2.82 * * * \\
(1.0)\end{array}$ & $\begin{array}{c}-3.10^{* * *} \\
(0.8)\end{array}$ & $\begin{array}{c}-4.21^{* * *} \\
(0.9)\end{array}$ & $\begin{array}{c}-3.53 * * * \\
(0.8)\end{array}$ & $\begin{array}{c}-2.58^{*} \\
(1.5)\end{array}$ & & $\begin{array}{c}-3.51^{* * *} \\
(0.8)\end{array}$ & $\begin{array}{c}-3.89 * * * \\
(1.0)\end{array}$ \\
\hline Trade openness & $\begin{array}{c}-0.096 * * * \\
(0.02)\end{array}$ & $\begin{array}{c}-0.083^{* * * *} \\
(0.02)\end{array}$ & $\begin{array}{c}-0.11 * * * \\
(0.02)\end{array}$ & $\begin{array}{c}-0.083^{* * *} \\
(0.02)\end{array}$ & $\begin{array}{l}-0.036 \\
(0.03)\end{array}$ & $\begin{array}{c}-0.067 * * * \\
(0.02)\end{array}$ & $\begin{array}{c}-0.089 * * * \\
(0.03)\end{array}$ & $\begin{array}{l}-0.010 \\
(0.03)\end{array}$ \\
\hline G7 growth & $\begin{array}{l}0.80^{*} \\
(0.4)\end{array}$ & $\begin{array}{c}1.16^{* * * *} \\
(0.3)\end{array}$ & $\begin{array}{c}0.99 * * * \\
(0.3)\end{array}$ & $\begin{array}{c}1.13^{* * * *} \\
(0.3)\end{array}$ & $\begin{array}{c}1.04 * * \\
(0.4)\end{array}$ & $\begin{array}{c}1.04^{* * *} \\
(0.3)\end{array}$ & $\begin{array}{c}1.14^{* * *} \\
(0.3)\end{array}$ & $\begin{array}{c}1.53^{* * *} \\
(0.3)\end{array}$ \\
\hline G7 interest rate & $\begin{array}{c}0.093 \\
(0.4)\end{array}$ & $\begin{array}{l}0.024 \\
(0.3)\end{array}$ & $\begin{array}{l}0.32 \\
(0.3)\end{array}$ & $\begin{array}{c}0.093 \\
(0.3)\end{array}$ & $\begin{array}{c}0.0046 \\
(0.4)\end{array}$ & $\begin{array}{c}-0.020 \\
(0.3)\end{array}$ & $\begin{array}{l}0.064 \\
(0.3)\end{array}$ & $\begin{array}{c}-0.72^{* *} \\
(0.3)\end{array}$ \\
\hline Expenditure & & & & & & & $\begin{array}{c}-0.55^{* * *} \\
(0.06)\end{array}$ & $\begin{array}{c}-0.27^{* * *} \\
(0.06)\end{array}$ \\
\hline Revenue & & & & & & & $\begin{array}{c}0.63^{* * *} \\
(0.07)\end{array}$ & \\
\hline Gross FDI & & & & & $\begin{array}{c}-0.16 \\
(0.1)\end{array}$ & & & \\
\hline Oil price volatility & & & & $\begin{array}{c}0.60^{* * *} \\
(0.2)\end{array}$ & & & & \\
\hline Oil price & & & $\begin{array}{c}6.19 * * * \\
(1.2)\end{array}$ & & & & & \\
\hline Credit & & $\begin{array}{c}-0.067^{* * *} \\
(0.02)\end{array}$ & & & & & & \\
\hline Constant & $\begin{array}{l}4.97 \\
(7.5) \\
\end{array}$ & $\begin{array}{l}-3.17 \\
(6.6) \\
\end{array}$ & $\begin{array}{l}6.64 \\
(5.5) \\
\end{array}$ & $\begin{array}{l}-5.84 \\
(6.5) \\
\end{array}$ & $\begin{array}{c}-9.88 \\
(12) \\
\end{array}$ & $\begin{array}{c}-11.1^{*} \\
(6.1) \\
\end{array}$ & $\begin{array}{r}-5.62 \\
(6.8) \\
\end{array}$ & $\begin{array}{l}-11.6 \\
(7.5) \\
\end{array}$ \\
\hline Fiscal balance (long-term) & $\begin{array}{c}0.82 * * * \\
(0.1)\end{array}$ & $\begin{array}{c}0.91^{* * *} \\
(0.08)\end{array}$ & $\begin{array}{c}0.82^{* * *} \\
(0.09)\end{array}$ & $\begin{array}{c}0.85^{* * * *} \\
(0.08)\end{array}$ & $\begin{array}{c}0.79 * * * \\
(0.1)\end{array}$ & $\begin{array}{c}0.94 * * * \\
(0.09)\end{array}$ & & \\
\hline \multicolumn{9}{|l|}{ Time dummies } \\
\hline $\mathrm{R}^{2}$ & 0.68 & 0.62 & 0.62 & 0.62 & 0.62 & 0.61 & 0.62 & 0.52 \\
\hline Adjusted $\mathrm{R}^{2}$ & 0.65 & 0.61 & 0.61 & 0.61 & 0.61 & 0.60 & 0.61 & 0.51 \\
\hline Observations & 399 & 396 & 399 & 399 & 316 & 402 & 399 & 399 \\
\hline Number of countries & 21 & 21 & 21 & 21 & 21 & 21 & 21 & 21 \\
\hline
\end{tabular}

Notes: Robust standard errors in parentheses.

*** significant at $1 \%$; ** significant at $5 \%$; * significant at $10 \%$.

The sample excludes outliers. Time dummies are not shown. 